\title{
15. NEOGENE CALCAREOUS NANNOFOSSIL BIOSTRATIGRAPHY, LEG 116 (CENTRAL INDIAN OCEAN) ${ }^{1}$
}

\author{
Stefan Gartner ${ }^{2}$
}

\begin{abstract}
The three sites $(717,718$, and 719$)$ drilled on the distal Bengal Fan during ODP Leg 116 cored turbidite sediments almost exclusively. Calcareous nannofossils were recovered sporadically and, although all of them probably have been redeposited, it is possible to date the sediments at all three sites with reasonable confidence. Site 717 penetrated the uppermost middle Miocene Catinaster coalitus highest occurrence datum and represents the most nearly continuous succession of turbidites. Site 718 penetrated the lower Miocene, well below the Helicosphaera ampliaperta highest occurrence datum, but this site contains a major late Pliocene to mid-Pleistocene hiatus. Site 719, the shallowest hole, penetrated only into the upper Miocene. Identification of several critical lowest occurrence datums allows using the poorly constrained but more numerous highest occurrence datums for comparison with the model succession (zonal markers) and thereby to derive a reasonably accurate time framework for the sediments.
\end{abstract}

\section{INTRODUCTION}

Three sites were drilled on the distal portion of the Bengal Fan during ODP Leg 116. The sites are located on the western side of the distal fan (Fig. 1) in an area where seismic profiles show conspicuous deformation of crust beneath the fan (Fig. 2). Deformation extends upward into the fan sediments but not to the fan surface. This deformation history of the older Bengal Fan sediments and the crust beneath was the principal objective of ODP Leg 116 drilling. From a paleontology-biostratigraphy standpoint all of the fan sediments, with the possible exception of a surface veneer of Holocene material, can be assumed to be turbidites. This assumption virtually requires that all fossils are redeposited. Actually, nearly all of the sediments recovered at the three sites have been identified unequivocally as turbidites; even the occasional thin laminae of calcareous ooze-type sediments often show graded bedding. Consequently it is probably safe to assume that all of the fossils are redeposited. Nevertheless, the calcareous nannofossils yielded an entirely usable, internally consistent - if sometimes rather crude-biostratigraphy for all three sites. The objective of this study is to present as much biostratigraphic information as could be gleaned from the nannofossils in these unpromising sediments. Unfortunately, the other planktonic fossil groups are so sparse and sporadic that they provide little ancillary biostratigraphic information. This contribution is partly a documentation of the nannofossils, which are the sole basis for the chronostratigraphy of these sediments. The age assignments presented here are not significantly different from those presented in Cochran, Stowe et al., 1989). Minor revisions resulted where fossiliferous samples were discovered in the cores and which permitted refinement of earlier determinations.

All three Leg 116 sites, 717, 718, and 719, are located in water depths close to the regional carbonate compensation depth (CCD) (Table 1). Consequently even the veneer of Holocene surface sediments yielded largely corroded microfossils. Moreover, the predominantly silty, sandy turbidites beneath this sur-

\footnotetext{
${ }^{1}$ Cochran, J. R., Stow, D.A.V., et al., 1990. Proc. ODP, Sci. Results, 116: College Station, TX (Ocean Drilling Program).

2 Department of Oceanography, Texas A\&M University, College Station, TX, 77843, U.S.A.
}

face veneer do not seem to favor preservation of any microfossils, and the nannofossils that were recovered are solution-resistant species, corroded and often with fewer than a half-dozen species representing the residue of the original assemblage. Occasional thin, clayey layers, most of them probably turbidites also, yielded relatively "rich" assemblages of up to a dozen species or more (Table 2). Lithologies that yielded nannofossils most consistently are the white or buff calcareous ooze layers, which are normally not more than a millimeter or two thick, green clayey layers a few millimeters to a few decimeters thick, and black clayey layers usually millimeters to centimeters thick. Lithologies that proved least productive of nannofossils, indeed all fossils, are bluish gray clays and massive, silty, sandy turbidites, although the clayey portion at the top of individual turbidite beds did yield a few scattered specimens. Some promisinglooking thin, white layers consist entirely of minute, euhedral carbonate rhombs (probably authigenic) with no fossil material among them.

Obviously a setting such as the Bengal Fan sediments drilled at the Leg 116 sites is far from ideal for any sort of microfossil biostratigraphy. A cautious approach requires the assumption that all fossils have been redeposited. It follows that all biohorizons identified may be younger in these sections, even if only incrementally, than in a normal pelagic succession. This, combined with significant intervals of poor or no fossil recovery, signals that the error bar one would attach to a particular biohorizon could be alarmingly large, but such errors are ultimately unpredictable. This problem is particularly keen for highest occurrence datums, which are the backbone of most microfossil biostratigraphies. Sparse recovery may actually make highest occurrences appear older than they are, whereas redeposition may make them appear younger. Lowest occurrences would be distorted in the same direction (i.e., toward a younger-than-actual age), both by sparse recovery and by redeposition. Fortunately downhole contamination generally is not a problem in ODP coring, and well-documented lowest occurrences are helpful for checking the reliability of the entire biostratigraphy, including highest occurrences. It is remarkable, therefore, to what extent the succession of biohorizons in Bengal Fan sediments, highest and lowest occurrences, matches the succession of these same biohorizons in pelagic sediments. This, and the similarity of biostratigraphy at the three sites, inspires a small measure of confidence in the results obtained from the nannofossils. 


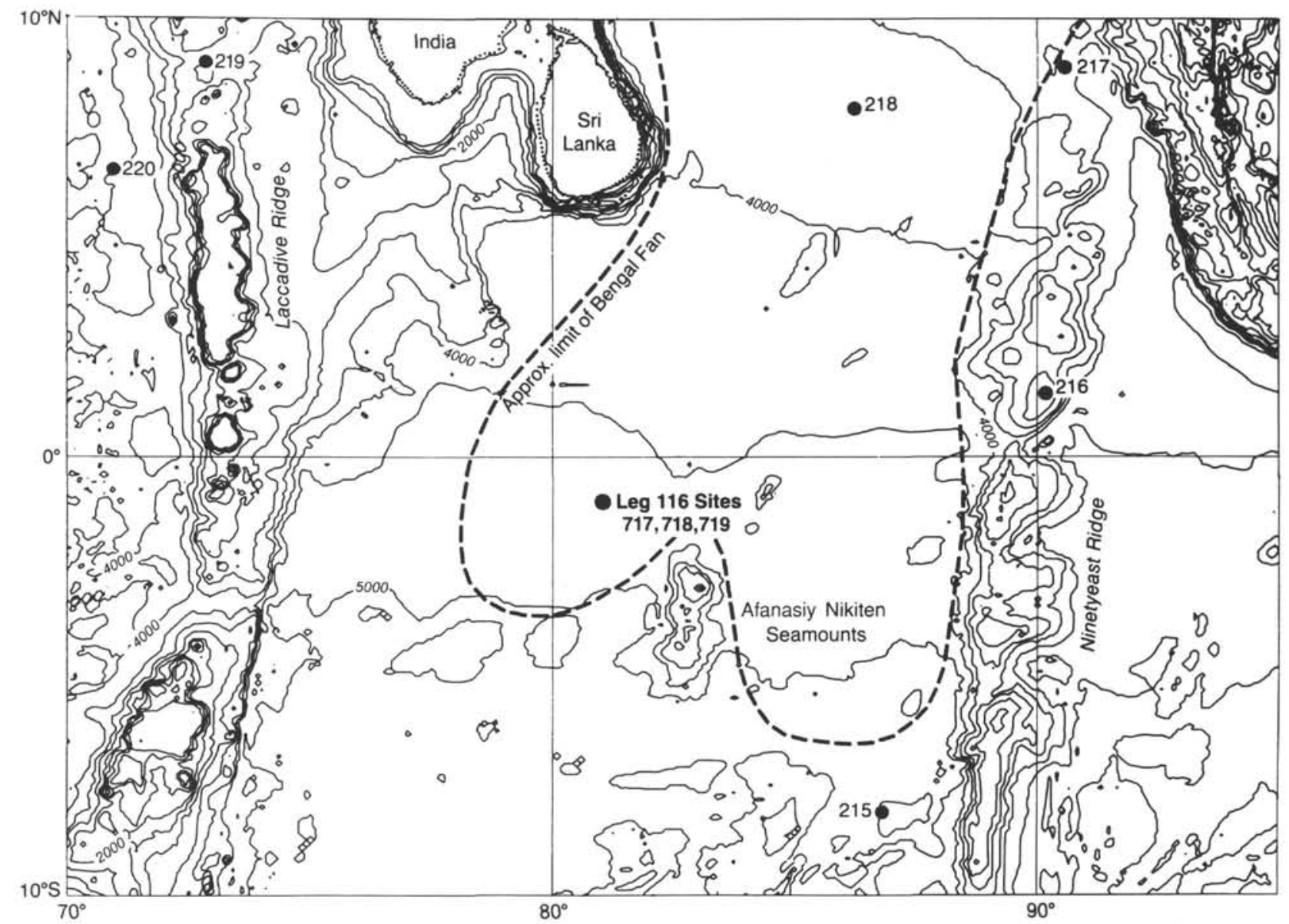

Figure 1. Location map, ODP Sites 717, 718, and 719. DSDP sites are also marked.

N

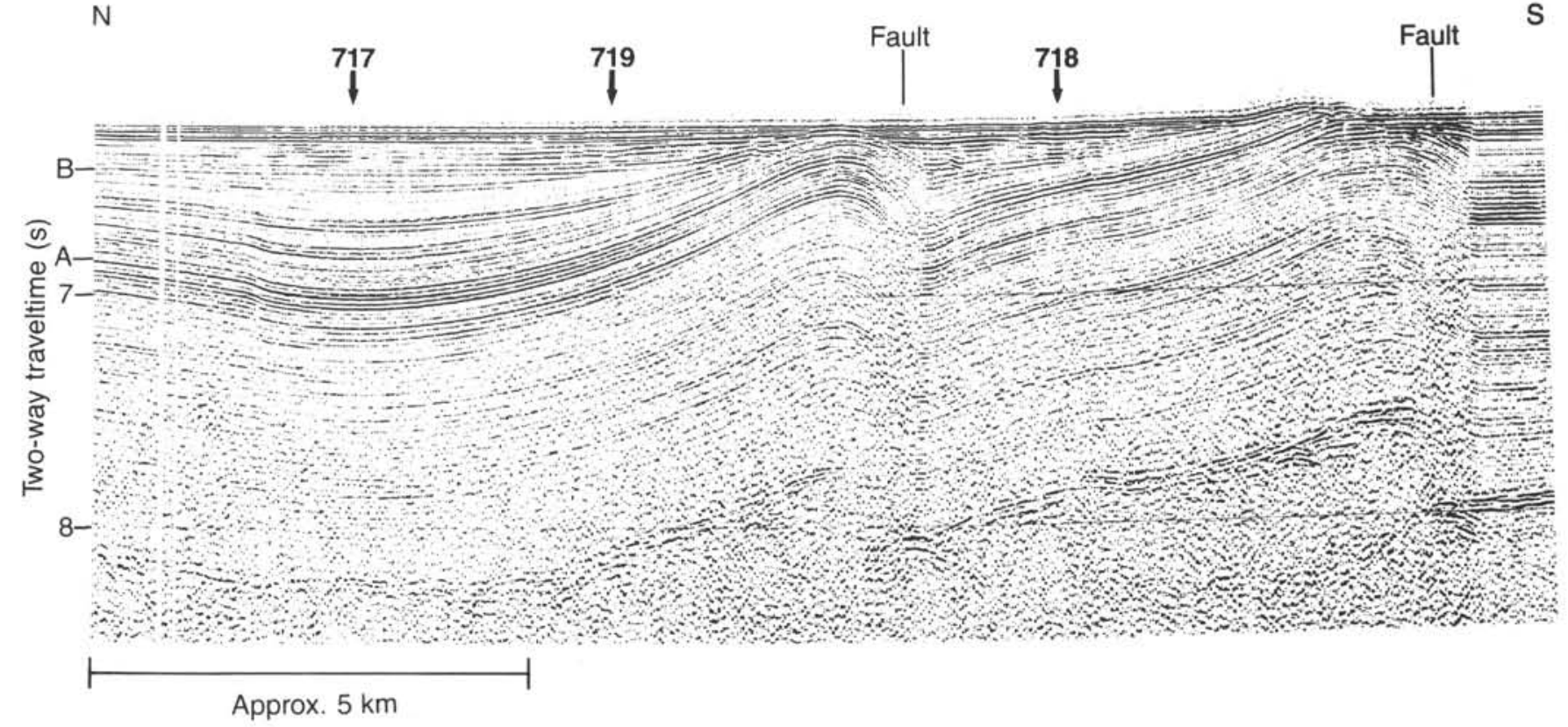

Figure 2. Seismic reflection profile through ODP Sites 717, 718, and 719. 
Table 1. Sites and holes drilled during ODP Leg 116 on the Bengal Fan.

\begin{tabular}{lcccr}
\hline Hole & $\begin{array}{c}\text { Latitude } \\
(\mathrm{S})\end{array}$ & $\begin{array}{c}\text { Longitude } \\
(\mathrm{E})\end{array}$ & $\begin{array}{c}\text { Water depth } \\
(\mathrm{m})\end{array}$ & $\begin{array}{c}\text { Penetration } \\
(\mathrm{mbsf})\end{array}$ \\
\hline 717A & $0^{\circ} 55.785^{\prime}$ & $81^{\circ} 23.408^{\prime}$ & 4734.7 & 9.5 \\
$717 \mathrm{~B}$ & $0^{\circ} 5.6^{\prime}$ & $81^{\circ} 24.0^{\prime}$ & 4734.7 & 13.5 \\
$717 \mathrm{C}$ & $0^{\circ} 55.785^{\prime}$ & $81^{\circ} 23.408^{\prime}$ & 4734.7 & 533.2 \\
& & & & \\
$718 \mathrm{~A}$ & $1^{\circ} 01.252^{\prime}$ & $81^{\circ} 24.065^{\prime}$ & 4741.3 & 9.5 \\
$718 \mathrm{~B}$ & $1^{\circ} 01.252^{\prime}$ & $81^{\circ} 24.065^{\prime}$ & 4741.3 & 18.8 \\
$718 \mathrm{C}$ & $1^{\circ} 01.252^{\prime}$ & $81^{\circ} 24.065^{\prime}$ & 4741.3 & 935.0 \\
$718 \mathrm{D}$ & $1^{\circ} 01.252^{\prime}$ & $81^{\circ} 24.065^{\prime}$ & 4741.3 & 19.0 \\
$718 \mathrm{E}$ & $1^{\circ} 01.252^{\prime}$ & $81^{\circ} 24.065^{\prime}$ & 4741.3 & 961.6 \\
& & & & \\
$719 \mathrm{~A}$ & $0^{\circ} 57.646^{\prime}$ & $81^{\circ} 23.967^{\prime}$ & 4747.3 & 460.2 \\
$719 \mathrm{~B}$ & $0^{\circ} 57.646^{\prime}$ & $81^{\circ} 23.967^{\prime}$ & 4747.3 & 465.6 \\
\hline
\end{tabular}

Table 2. Nannofossil datum levels, their ages, and depths in the distal Bengal Fan, ODP Sites 717, 718, and 719.

\begin{tabular}{|c|c|c|c|c|}
\hline \multirow[b]{2}{*}{ Nannofossil Datum } & \multirow{2}{*}{$\begin{array}{l}\text { Age } \\
(\mathrm{m} . \mathrm{y} .)\end{array}$} & \multicolumn{3}{|c|}{ Depth (mbsf) } \\
\hline & & Site 717 & Site 718 & Site 719 \\
\hline Pseudoemiliania lacunosa H.O. & 0.465 & 74.50 & 47.30 & 32.70 \\
\hline small Gephyrocapsa Acme H.O. & 0.93 & 203.42 & & 151.60 \\
\hline Helicosphaera sellii H.O. & 1.27 & 203.53 & & \\
\hline Gephyrocapsa oceanica s.I. L.O. & 1.59 & 217.25 & 113.80 & 154.62 \\
\hline Discoater brouweri H.O. & 1.88 & 219.08 & & 163.10 \\
\hline Discoaster pentaradiatus H.O. & 2.29 & 233.65 & & 163.23 \\
\hline Discoaster surculus H.O. & 2.42 & 245.50 & & 166.39 \\
\hline Discoaster variabilis H.O. & 2.90 & 278.76 & & \\
\hline Sphenolithus abies H.O. & 3.45 & 306.95 & & 194.20 \\
\hline $\begin{array}{l}\text { Reticulofenestra } \\
\text { pseudoumbilica H.O. }\end{array}$ & 3.51 & 321.50 & & 203.70 \\
\hline Pseudoemiliania lacunosa L.O. & 4.00 & 350.00 & 126.06 & 231.91 \\
\hline Ceratolithus armatus L.O. & 5.06 & 416.50 & & 275.77 \\
\hline Discoaster quinqueramus H.O. & 5.26 & 424.41 & 159.28 & 283.84 \\
\hline Discoaster berggrenii H.O. & 5.80 & 464.00 & 169.00 & 352.99 \\
\hline Amaurolithus amplificus L.O. & 5.90 & 480.57 & & 393.86 \\
\hline Amaurolithus primus L.O. & 6.74 & & 183.63 & \\
\hline Discoaster quinqueramus L.O. & 8.20 & 673.00 & 341.80 & \\
\hline Discoaster hamatus H.O. & 8.85 & 819.41 & 360.80 & \\
\hline Catinaster coalitus H.O. & 9.00 & 820.40 & 391.44 & \\
\hline Catinaster coalitus L.O. & 10.80 & & 561.31 & \\
\hline Cyclicargolithus floridanus H.O. & 11.03 & & 645.80 & \\
\hline Sphenolithus heteromorphus H.O. & 13.17 & 678.74 & & \\
\hline Helicosphaera ampliaperta H.O. & 16.20 & & 778.80 & \\
\hline
\end{tabular}

H.O. $=$ highest occurrence; L.O. = lowest occurrence .

\section{PROCEDURE}

The nannofossil biostratigraphy for this study (Fig. 3) follows essentially the compilation of Perch-Nielsen (1985), which is closely tied to the comprehensive zonations of Bukry (1971; see also Okada and Bukry, 1980) and Martini (1971). Additional biohorizons have been inserted that are not part of the above zonations but that have been variously documented (see caption for Fig. 3). Some of these (e.g., the lowest occurrence of Gephyrocapsa oceanica and the lowest occurrence of Pseudoemiliania lacunosa) proved particularly useful for assigning ages in the difficult turbidite sections of the Bengal Fan.

The chronostratigraphy follows closely the compilation of Berggren et al. (1985a; see Fig. 3). There are some minor discrepancies from ages assigned to some nannofossil biohorizons, based largely on data developed within the past few years and not available at the time of the earlier compilation. Particularly important are the results from DSDP Leg 94 (Clement and Robinson, 1987; Takayama and Sato, 1987; Baldauf et al., 1987).

The greatest departure from the age assignments of Berggren et al. (1985a) is in the middle Miocene and the lower Miocene (highest occurrence of Cyclicargolithus floridanus; lowest occurrence of Triquetrorhabdulus rugosus; and highest occurrences of Sphenolithus heteromorphus and Helicosphaera ampliaperta). Berggren et al. (1985a) based their age assignments on uncertain correlations to magnetic reversal stratigraphy in Miller et al. (1985). More recent age assignments are from DSDP Leg 94. Unfortunately these data, too, are imperfect. Both age assignments are presented, the alternative ages from Leg 94 being identified by the letter $\mathrm{A}$ in square brackets on Figure 3 . A summary of age assignments for the three sites of Leg 116 is given also in Figure 3.

Sample spacing throughout the cores from the three sites is notably uneven, which is occasioned by the distribution of favorable fossiliferous lithologies within the turbidite sequences. Also, a large number of barren samples were not included in the checklist, although some barren samples have been included to convey the flavor of the sections recovered in the cores.

\section{SAMPLE PREPARATION AND DOCUMENTATION}

All samples were prepared using the same technique to maintain uniformity. A small sample was spread onto a cover glass with a drop of water and filming agent. All samples disaggregated readily, and the grain sizes of all components of the sediment were sufficiently fine so that separation by size fraction was neither necessary nor practical. The cover glass was mounted according to standard procedures. All determinations were made using a light microscope. Relative abundances of individual species are recorded semi-quantitatively in six abundance categories at a nominal magnification of $1250 \times$ : very abundant $=>80 \%$ of a rich assemblage; abundant $=>100$ specimens encountered; common $=20$ to 100 specimens encountered; few $=6$ to 20 specimens encountered; rare $=3$ to 5 specimens encountered; very rare $=1$ to 2 specimens encountered. Scanning time varied from approximately $15 \mathrm{~min}$ for productive samples to as much as $30 \mathrm{~min}$ for relatively unproductive but critical samples.

\section{BIOSTRATIGRAPHIC EVALUATION}

\section{Site 717}

Site 717 is located on flat seafloor above the axis of a structural depression, so that the post-deformation sedimentary deposit is thickest at this site (Fig. 2). The sediment section cored at this site was divided into several distinct lithologic units based on dominant lithology of the turbidites (Cochran, Stow, et al., 1989). Nannofossil recovery is closely related to this lithostratigraphy. A checklist of the calcareous nannofossils recovered at this site is given in Figures 4, 5, and 6. Holes 717A (Fig. 4) and 717B (Fig. 5) tested mainly the surface sediments. Good-to-fair nannofossil recovery was obtained from the clayey sediments (Unit I) at the top of these two holes, although dissolution is obvious, and at some levels the assemblage is residual. Sandy, silty layers are barren. Most abundant are Gephyrocapsa oceanica s.1. and Florisphaera sp.; however, the significance of this abundance is unclear because of the residual nature of the assemblage. Emiliania huxleyi is present to about $5.3 \mathrm{~m}$ below the seafloor (mbsf) (Sample 116-717A-1H-4, $80 \mathrm{~cm}$ ) but not at 9.5 mbsf (Sample 116-717A-1H, CC). Redeposited Neogene species (not tabulated) are present near the surface, attesting to the continued redeposition of nannofossils even today.

Hole $717 \mathrm{C}$ yielded 91 cores and penetrated to the top of the middle Miocene. Catinaster coalitus was recovered from Sample $116-91-2 \mathrm{H}, 20 \mathrm{~cm}$ ( $820.4 \mathrm{mbsf})$, a few meters from the bottom of the hole (Fig. 6). Nannofossil recovery throughout the cores from this hole is sporadic and preservation is poor. Redeposition is a constant factor. Only by disallowing nonconsecutive occurrences of common species and by requiring an internal consistency in the succession of biohorizons (conformity of the 


\section{S. GARTNER}

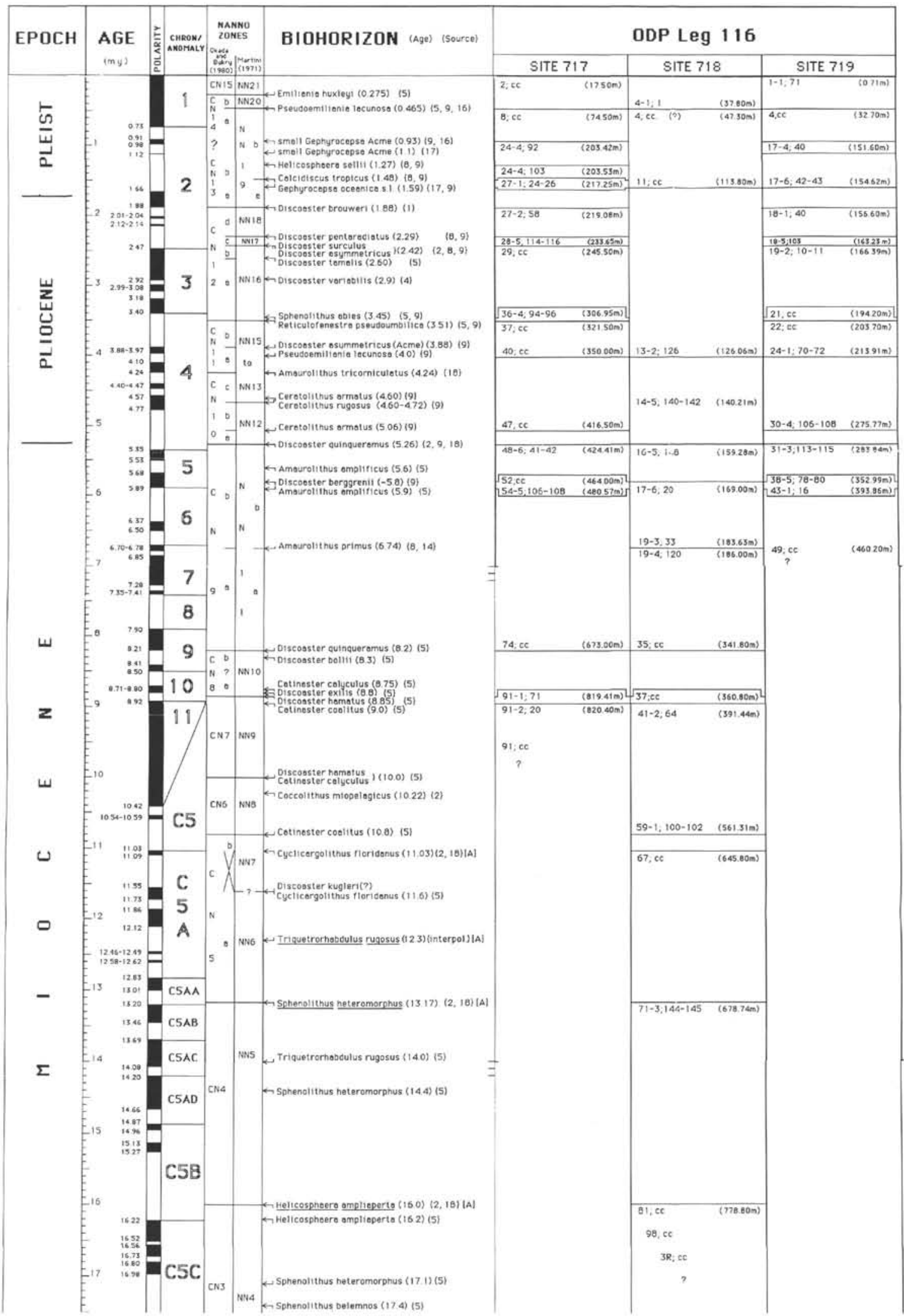

Figure 3. Nannofossil datum succession and chronology. The best date for each datum is given in parentheses. The sources of the data are indicated in brackets: [1-Baldauf et al., 1987; 2-Berggren et al., 1985b; 3-Gartner et al., 1983; 4-Gartner, unpubl. data; 5-Poore et al., 1984; 6-Prell et al., 1986; 7-Rio et al., 1988; 8-Takayama and Sato, 1987]. [A] indicates an alternative age assignment for that particular biohorizon. 


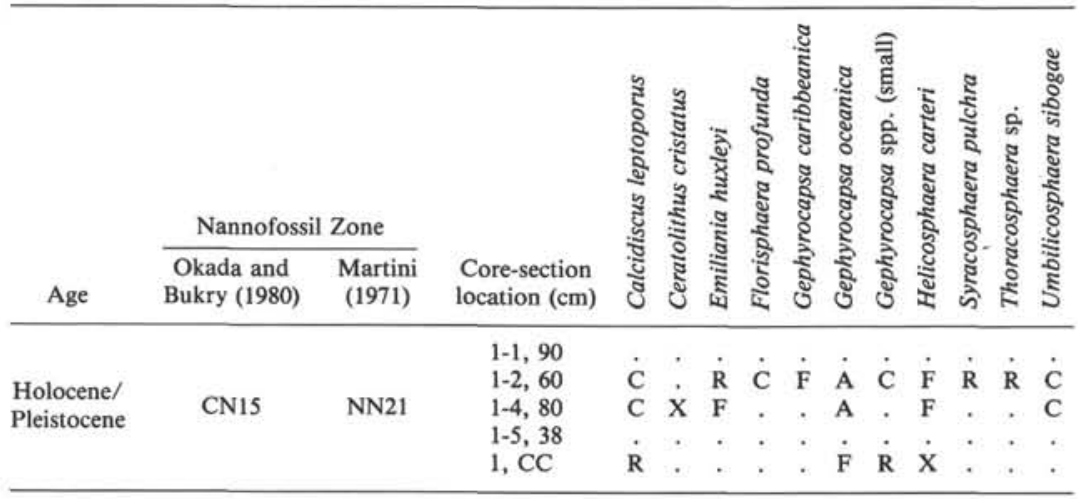

Key to symbols: $\mathrm{X}=$ very rare; $\mathrm{R}=$ rare; $\mathrm{F}=$ few; $\mathrm{C}=$ common; $\mathrm{A}=$ abundant; $\mathrm{W}=$ very abundant; ? = questionably present; . = not present.

Figure 4. Checklist of calcareous nannofossils, Hole 717A.

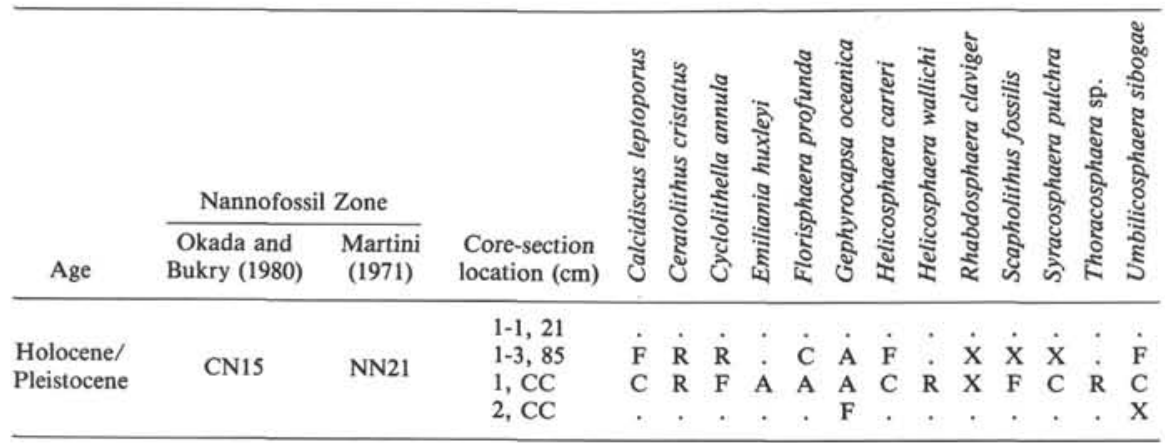

Key to symbols: $\mathrm{X}=$ very rare; $\mathrm{R}=$ rare; $\mathrm{F}=$ few; $\mathrm{C}=$ common; $\mathrm{A}=$ abundant; $\mathrm{W}=$ very abundant; ? = questionably present; . = not present.

Figure 5. Checklist of calcareous nannofossils, Hole 717B.

succession to the reference succession) is it possible to establish a reasonable, although perhaps somewhat synthetic, chronological framework for this hole.

The youngest biohorizon recognized in Hole $717 \mathrm{C}$ is the highest occurrence of Pseudoemiliania lacunosa in Core 116-717C$8 \mathrm{H}, \mathrm{CC}(74.5 \mathrm{mbsf})$, which is within lithologic Unit II, a sequence of massive silty turbidites. This datum is poorly constrained because of the poor fossil recovery from this unit. However, below this sample the marker species is recorded more or less consistently. The single, isolated higher occurrence in Sample $116-717 \mathrm{C}-5 \mathrm{H}, \mathrm{CC}$ ( $46 \mathrm{mbsf}$ ), is assumed to be redeposited. Poor recovery of nannofossils continues throughout Unit II, which extends to Core 116-717C-20X (approximately $152 \mathrm{mbsf}$ ). Below this level nannofossil recovery improves in the more clayey and calcareous Unit III, although preservation remains poor. Stratigraphic resolution is not improved as much, perhaps all, of Unit III consists of turbidites as well, and the lower sedimentation rate associated with these finer sediments may further exaggerate the bias introduced by redeposition.

The next lower datum, the top of the interval of dominance of small Gephyrocapsa (with large Gephyrocapsa reduced or absent) is interpreted to be in Sample 116-717C-24X-4, $92 \mathrm{~cm}$ (203.42 mbsf), followed immediately by the Helicosphaera sellii highest occurrence in Sample 116-717C-24X-4, $103 \mathrm{~cm}(203.53$ mbsf). The proximity of the two datums suggests either a hiatus or greatly attenuated sedimentation. However, either one or both of these datums may be incorrectly interpreted. Very low sediment accumulation persists to the next lower datum, the lowest occurrence of Gephyrocapsa oceanica s.l. in Sample 116-717C$27 \mathrm{X}-1,24-26 \mathrm{~cm}$ (217.25 mbsf).

Rio et al. (1988) noted that this datum is especially useful in sections where redeposition is a problem. This is important in Hole 717C because Discoaster brouweri and Discoaster pentaradiatus both occur in Sample 116-717C-26X, CC (217 mbsf), above the lowest occurrence of Gephyrocapsa oceanica s.l. They are obviously redeposited. The highest occurrences of Discoaster brouweri and of Discoaster pentaradiatus are placed in Samples 116-717C-27X-2, $58 \mathrm{~cm}$ (219.08 mbsf), and 116-717C-28X-5, $114-116 \mathrm{~cm}$ ( $241.15 \mathrm{mbsf})$, respectively, where the two species are well represented, although there is some evidence for redeposition (e.g., the occurrence of Sphenolithus abies). These datums may be moved upward or downward without violating the data or the order of succession because the next lower datum, the highest occurrence of Discoaster surculus, is in Sample 116$717 \mathrm{C}-29 \mathrm{X}, \mathrm{CC}(245.5 \mathrm{mbsf})$, in which there are no unequivocally redeposited older species. The highest occurrence of Discoaster variabilis, placed in Sample 116-717C-33X-4, 125-127 cm ( $278.76 \mathrm{mbsf})$, is very weakly manifested, partly perhaps because nannofossil recovery deteriorates from Core 116-717C-31X downward approximately to Core $116-717 \mathrm{C}-40 \mathrm{X}$. Consequently the next three datums are best evaluated together. The guiding datum is the lowest occurrence of Pseudoemiliania lacunosa in Sample 116-717C-40X, CC (350 mbsf). Above this are the highest occurrences of Sphenolithus abies and of Reticulofenestra pseudoumbilica in Sample 116-717C-36X-4; 94-96 cm (306.95 mbsf), and 116-717C-37X, CC (321.5 mbsf), respectively. From 


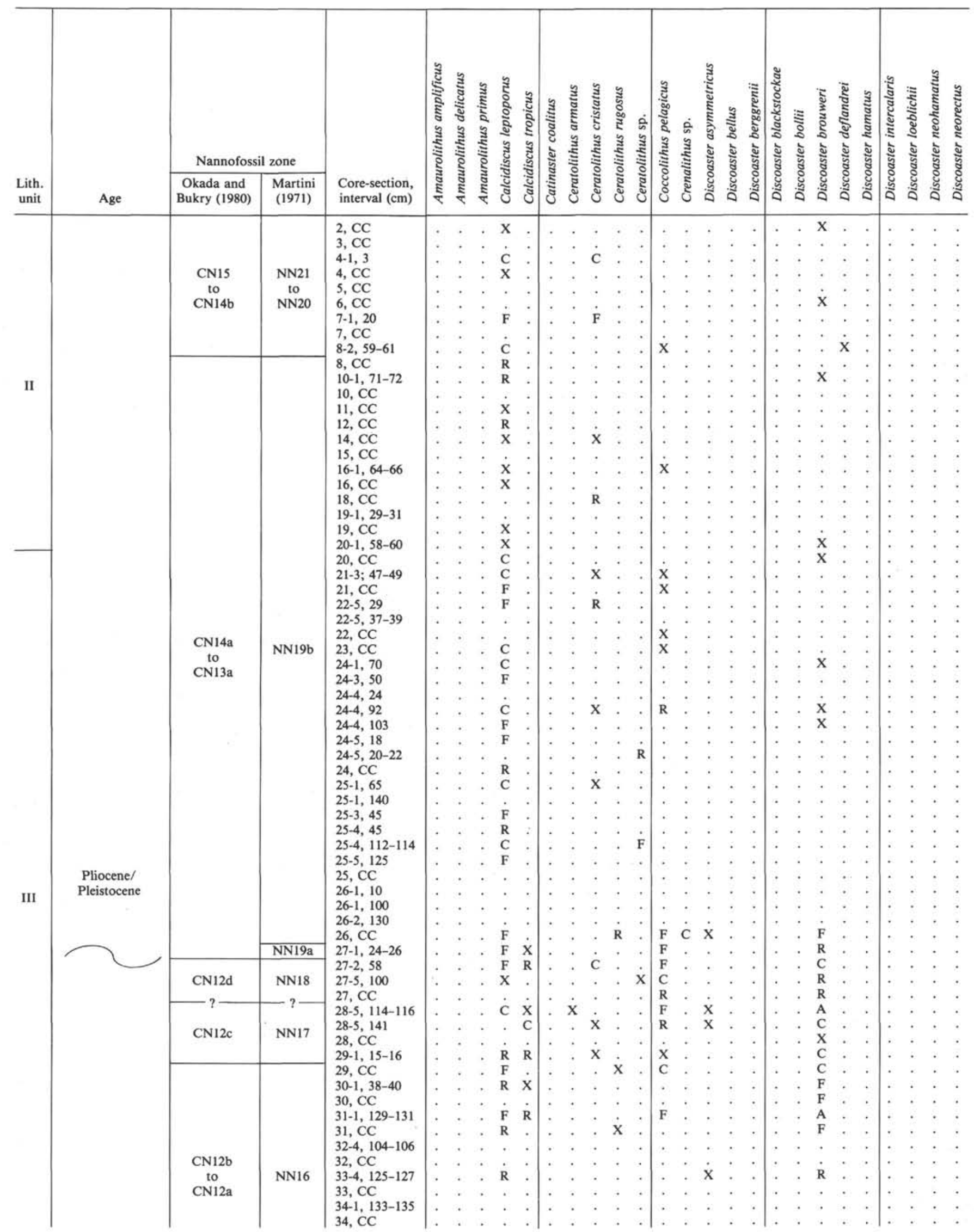

Figure 6. Checklist of calcareous nannofossils, Hole 717C. 


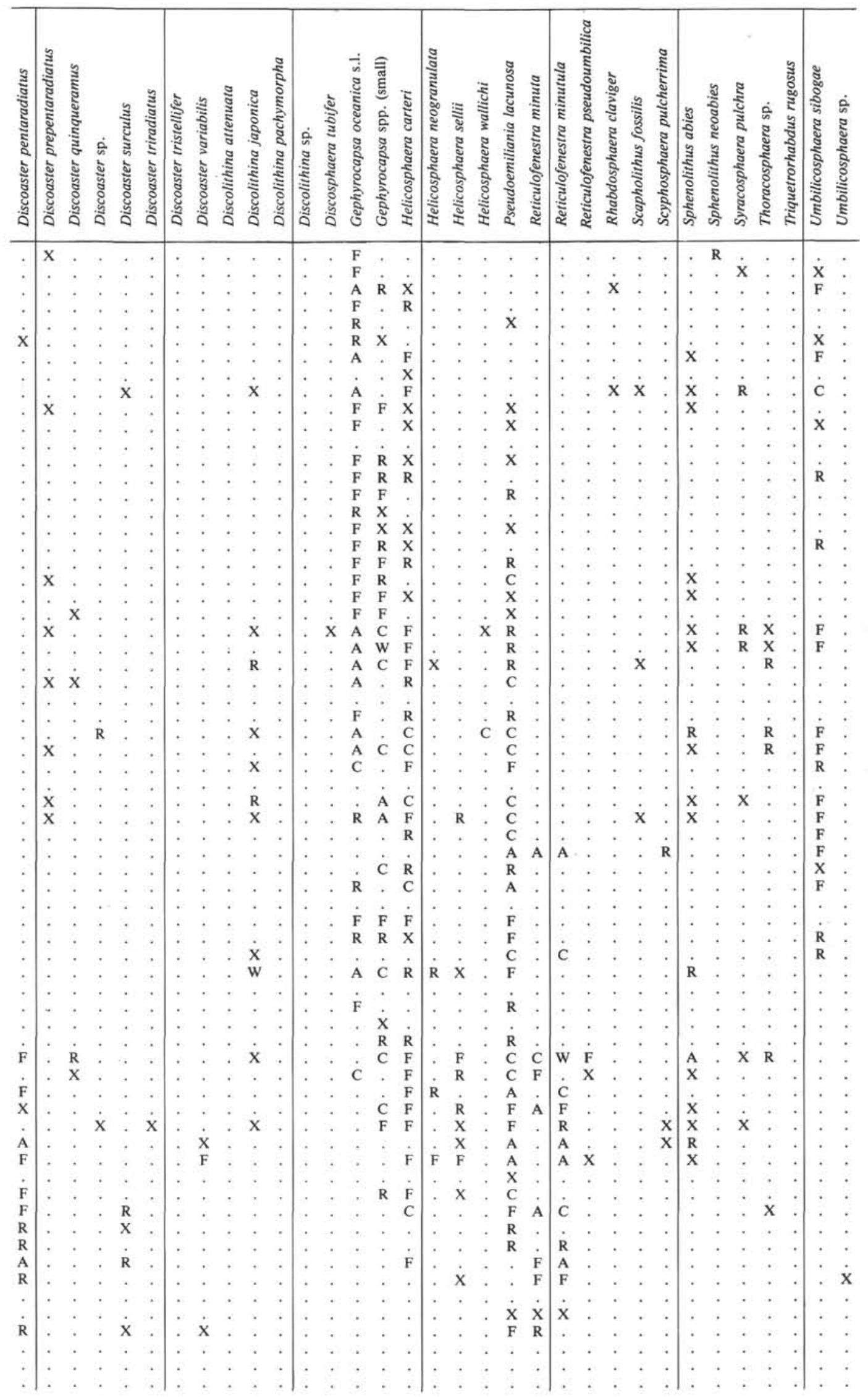

Figure 6 (continued). 


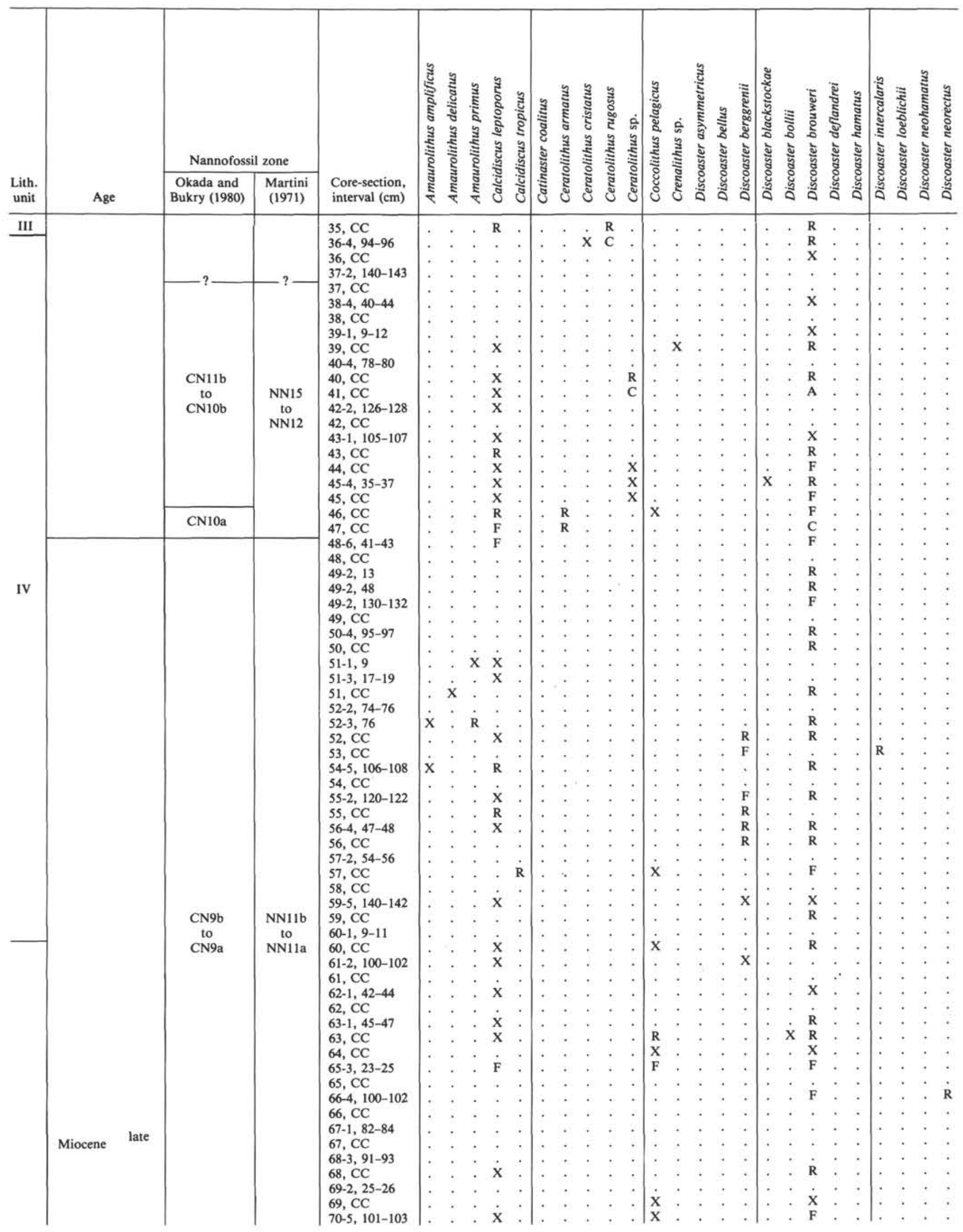

Figure 6 (continued). 


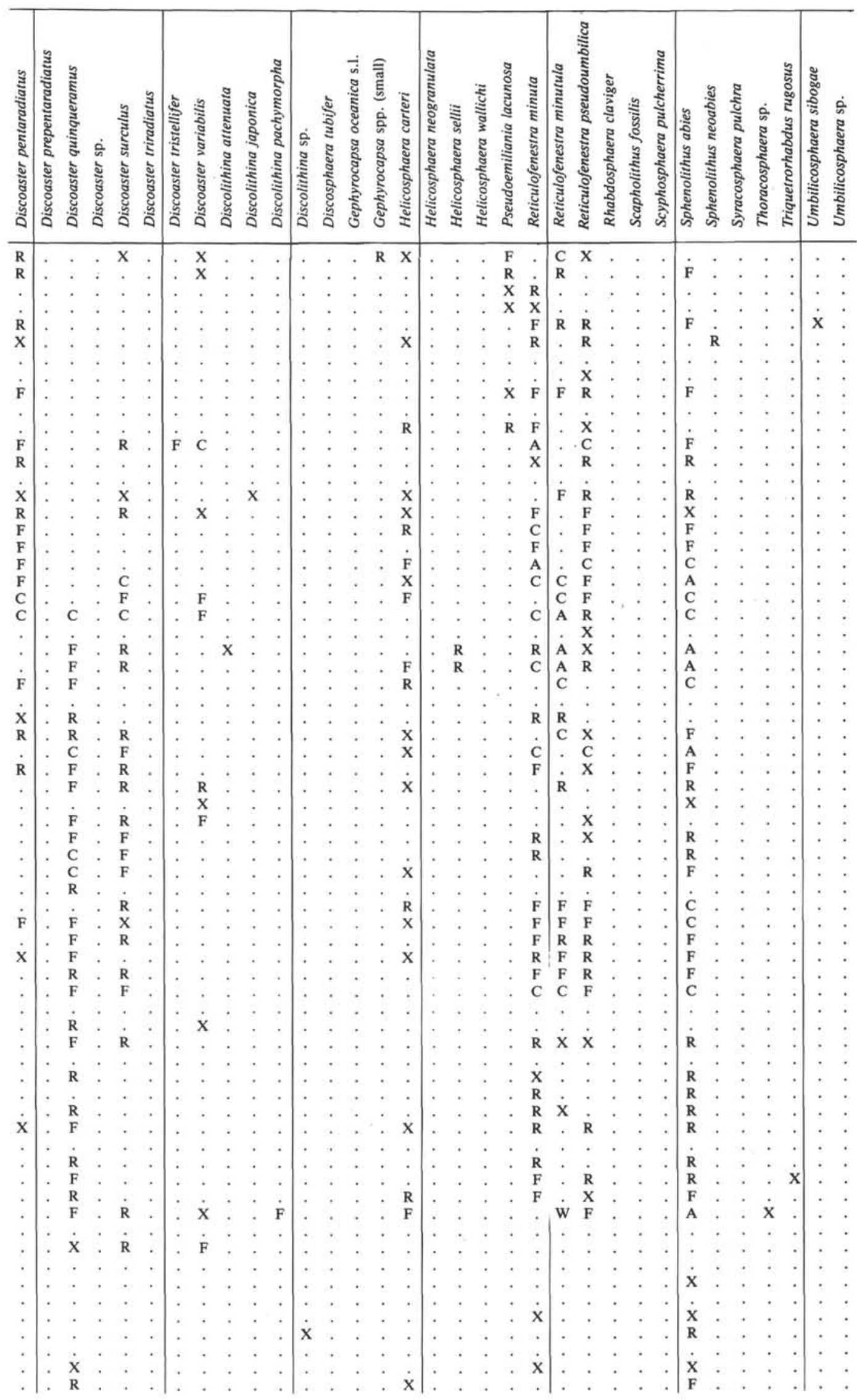

Figure 6 (continued). 


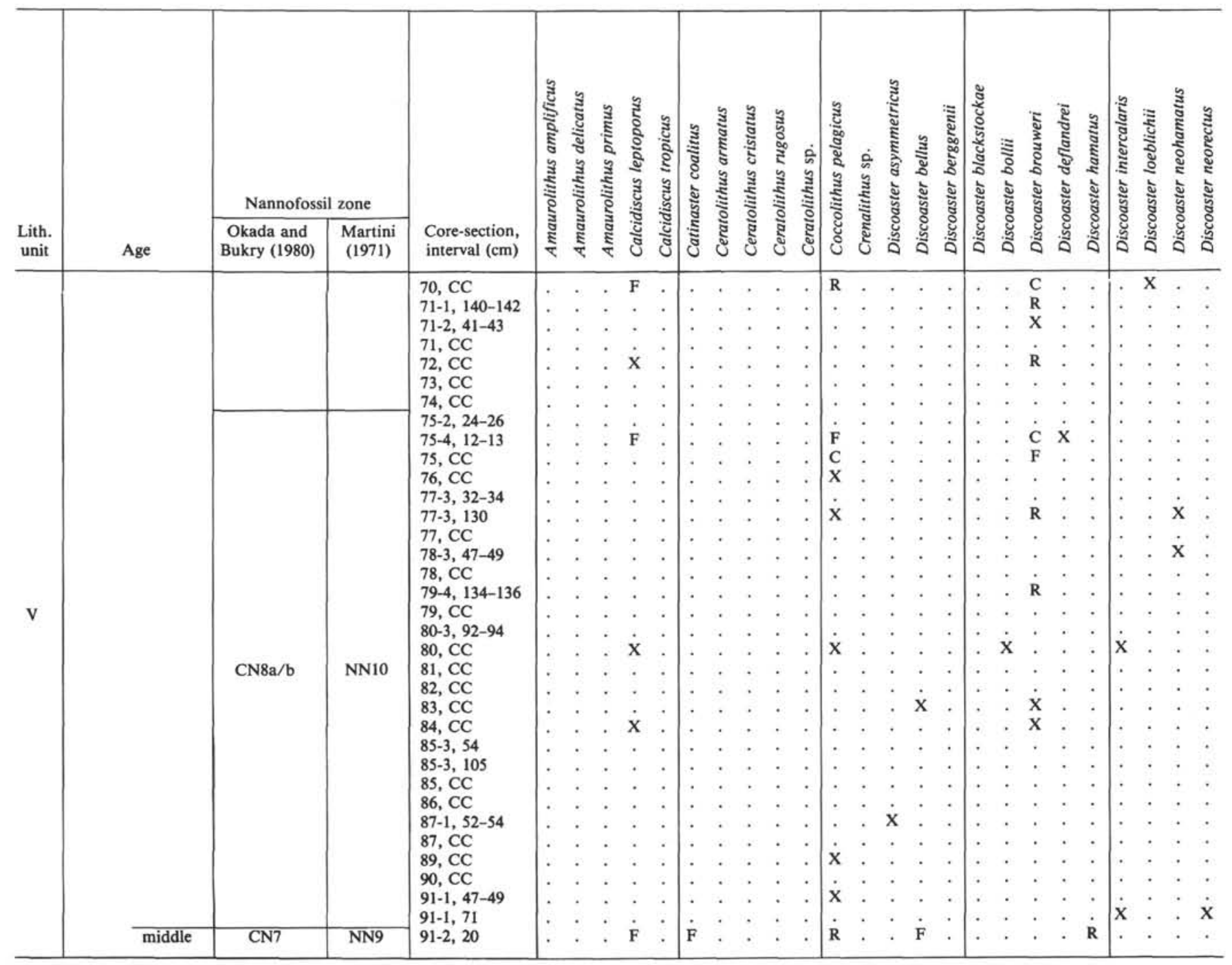

Key to symbols: $\mathrm{X}=$ very rare; $\mathbf{R}=$ rare; $\mathrm{F}=$ few; $\mathrm{C}=$ common; $\mathrm{A}=$ abundant; $\mathrm{W}=$ very abundant; ? = questionably present; . $=$ not present.

Figure 6 (continued).

these levels down, both species are present abundantly and persistently, and the pattern of the three datums is similar to the reference succession. Higher occurrences of the last two species are regarded as redeposited into significantly younger sediments.

The next two datums also need to be evaluated together. These are the lowest occurrence of Ceratolithus armatus in Sample 116-717C-47X, CC (416.5 mbsf), and the highest occurrence of Discoaster quinqueramus in Sample 116-717C-48X-6, 41-43 $\mathrm{cm}$ (424.41 mbsf). Several meters of barren turbidite occur between these two samples; however, the order of the succession is as expected, and significant upward displacement of the Discoaster quinqueramus highest occurrence is not likely because these datums are in an interval of reasonably good recovery of nannofossils. Fair recovery continues downward for some distance, and the next lower datum, the lowest occurrence of Amaurolithus amplificus in Sample 116-717C-54X-5, 106-108 cm (480.57 mbsf), is considered reasonably reliable even though it is based on very rare occurrence of the marker species in only two samples. Discoster berggrenii has its highest occurrence in Sample 116-717C$52 \mathrm{X}, \mathrm{CC}$ (464 mbsf), thus overlapping the range of Amaurolithus amplificus although it does not extend to the highest occurrence of Amaurolithus amplificus and terminates well below the highest occurrence of Discoaster quinqueramus. The same pattern is recognizable in a reference section on the northwest
Florida continental shelf (Gartner et al., 1983, and Gartner, unpubl. data). This is not compatible with the age (5.6 m.y.) assigned to this datum by Berggren et al. (1985a), based on observations by Mazzei et al. (1979) at DSDP Site 397. The true age of the datum must be older, probably close to $5.8 \mathrm{~m}$.y. Although the exact range of Discoaster berggrenii in relation to magnetic reversal stratigraphy, and hence, the precise age of its highest occurrence, remains unresolved, the age given in Figure 3 probably is a reasonable approximation.

The remaining datums from this hole, except perhaps those nearest the bottom, are weak in that they are based on very rare and sporadic occurrences. The next lower datum is marked by one rare occurrence of Discoaster loeblichii in Sample 116-717C$70 \mathrm{X}, \mathrm{CC}$ (635 mbsf) (no magnetostratigraphic calibration available), followed a short distance below by the lowest occurrences of Discoaster quinqueramus and Discoaster surculus in Sample 116-717C-74X, CC (673 mbsf). Of the three, only Discoaster quinqueramus occurs with sufficient consistency to be considered at all reliable as a marker. Unfortunately the age of 8.2 m.y. assigned to this datum by Berggren et al. (1985a) is not as well constrained by magnetic stratigraphy as is desirable.

Poor nannofossil recovery continues to the bottom of the hole. Among the marker species encountered are very rare occurrences of Discoaster neohamatus in Samples 116-717C-77X-3, 


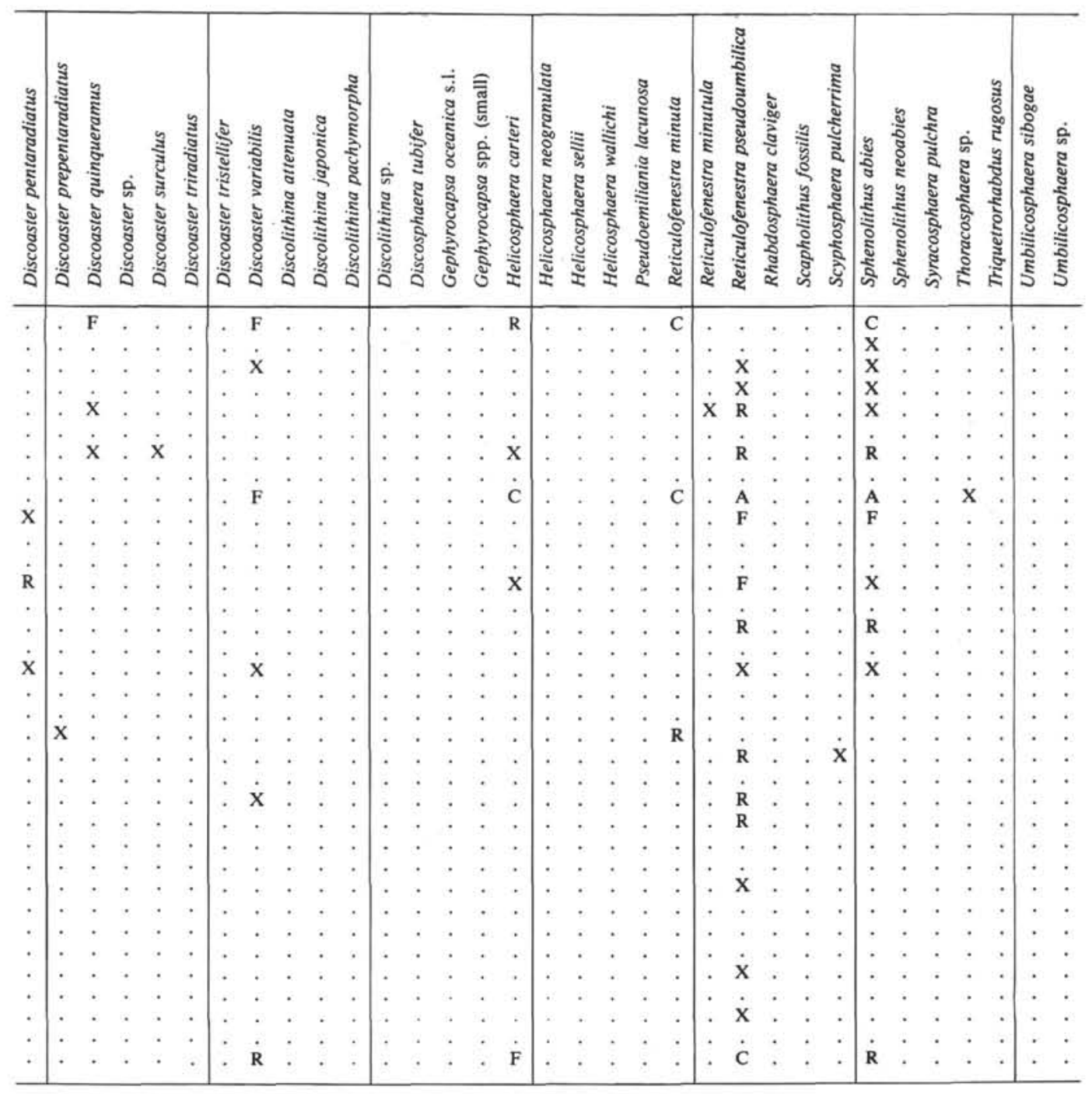

Figure 6 (continued).

$130 \mathrm{~cm}$ (696.3 mbsf), and 116-717C-78X-3, 47-49 cm (704.98 mbsf) (no magnetostratigraphic calibration available), and one very rare occurrence of Discoaster hamatus in Sample 116-717C$91 \mathrm{X}-1,71 \mathrm{~cm}$ (819.41 mbsf). Although these occurrences are in the correct order, recovery is too sparse to assign great significance to them.

The lowermost datum identified at Site $717 \mathrm{C}$ is the highest occurrence of Catinaster coalitus in Sample 116-717C-91X-2, $20 \mathrm{~cm}$ ( $820.4 \mathrm{mbsf})$, only a few meters above the bottom of the hole. Coccolith recovery from this section is moderate and without obvious contamination, and the marker species is sufficiently abundant to inspire confidence in this datum. The age limits assignable to this level are not greater than $10.8 \mathrm{~m}$.y. (lowest/oldest occurrence of Catinaster coalitus) to $9.0 \mathrm{~m}$.y. (highest/youngest occurrence of Catinaster coalitus), possibly incrementally younger, assuming redeposition of the entire assemblage.

\section{Site 718}

Site 718 also is located on the flat surface of the Bengal Fan, south of Site 717 but on a different structural block (Fig. 2). The post-deformation sediment cover is much thinner at Site 718 and older sediments are closer to the surface. Holes $718 \mathrm{~A}$ and $718 \mathrm{~B}$ tested the surface sediments. A residual assemblage of nannofossils of mixed Pleistocene age was recovered from turbi- dite muds and silts, contaminated with rare Neogene species. Probably the principal mode of nannofossil emplacement in the sediment is by redeposition by turbidity flows. Pelagic sedimentation does not seem to be significant. Hole $718 \mathrm{C}$ penetrated to 935 mbsf; the oldest biohorizon recognized is the highest occurrence of Helicosphaera ampliaperta in Sample 116-718C-81X, CC (778.8 mbsf), which indicates an early Miocene age. A checklist of nannofossils for Hole $718 \mathrm{C}$ is given in Figure 7. Core 116$718 \mathrm{C}-1$ at the top of the checklist is actually from Hole $718 \mathrm{~B}$ because Core 1 from Hole $718 \mathrm{C}$ yielded virtually no recovery. The lowermost three cores $(1 \mathrm{R}-3 \mathrm{R})$ are from Hole $718 \mathrm{E}$.

The succession of biohorizons at Site 718 is less distinctive, especially over the Pleistocene and Pliocene interval, than at Site 717 . In addition to the generally unfavorable lithology of the Pleistocene, biostratigraphic evaluation is hampered further by unusually poor fossil recovery. Also, the Pliocene section is greatly attenuated or riddled with hiatuses.

The youngest recognizable biohorizon is the highest occurrence of Pseodoemiliania lacunosa in Sample 116-718C-4X, CC (47.30 mbsf). Two higher occurrences (Samples 116-718C-2X, CC (28.30 mbsf) and 116-718C-3X, CC (37.80 mbsf), are disregarded because intervening samples, that reasonably could be expected to, do not contain the species. In a sense, however, the occurrence of the marker species in Samples 116-718C-4X, CC, is 


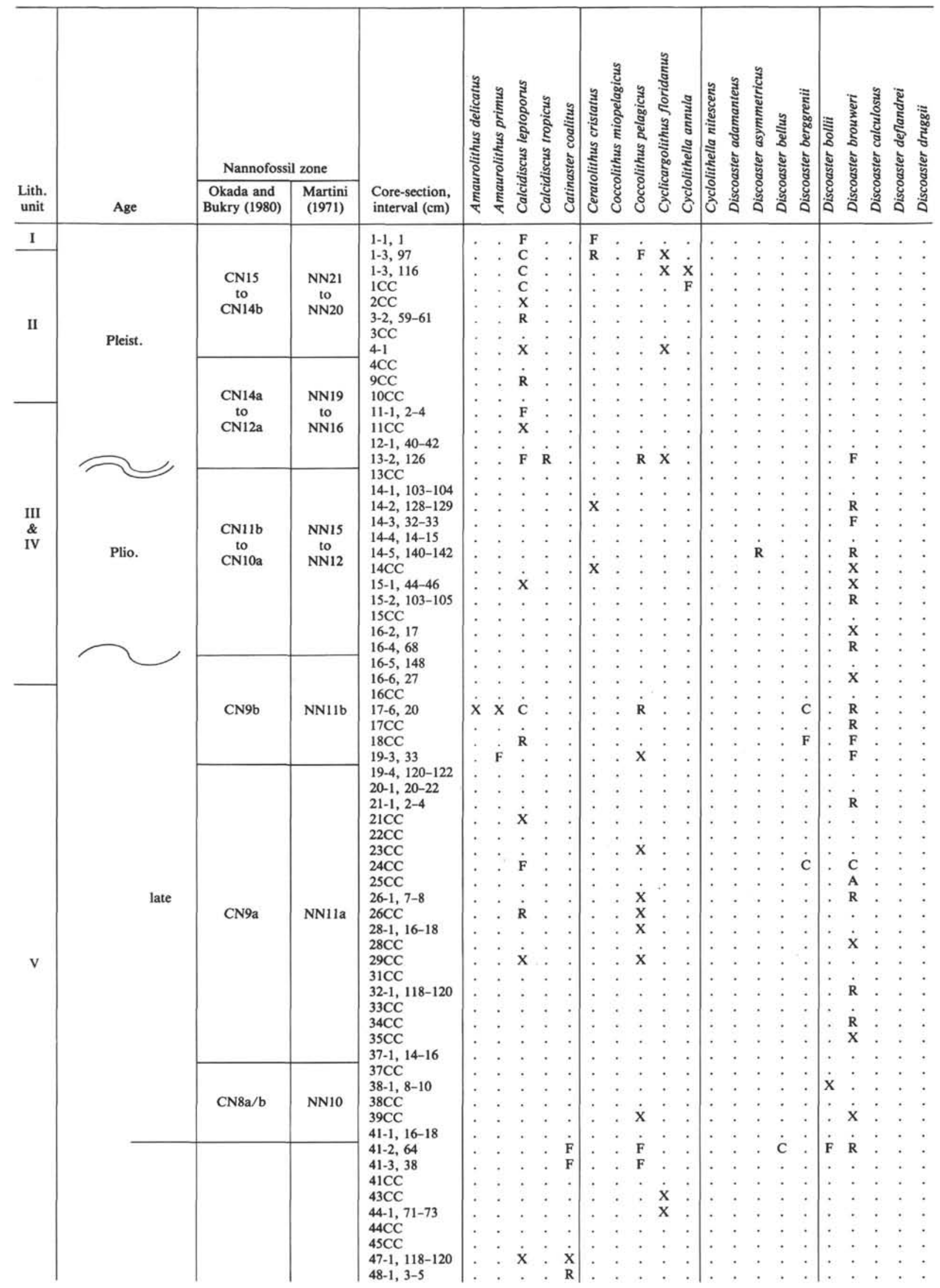

Figure 7. Checklist of calcareous nannofossils, Holes 717B (Core 1), 717C (Cores 2 to 98), and 717E (Cores 1 R/3R). 


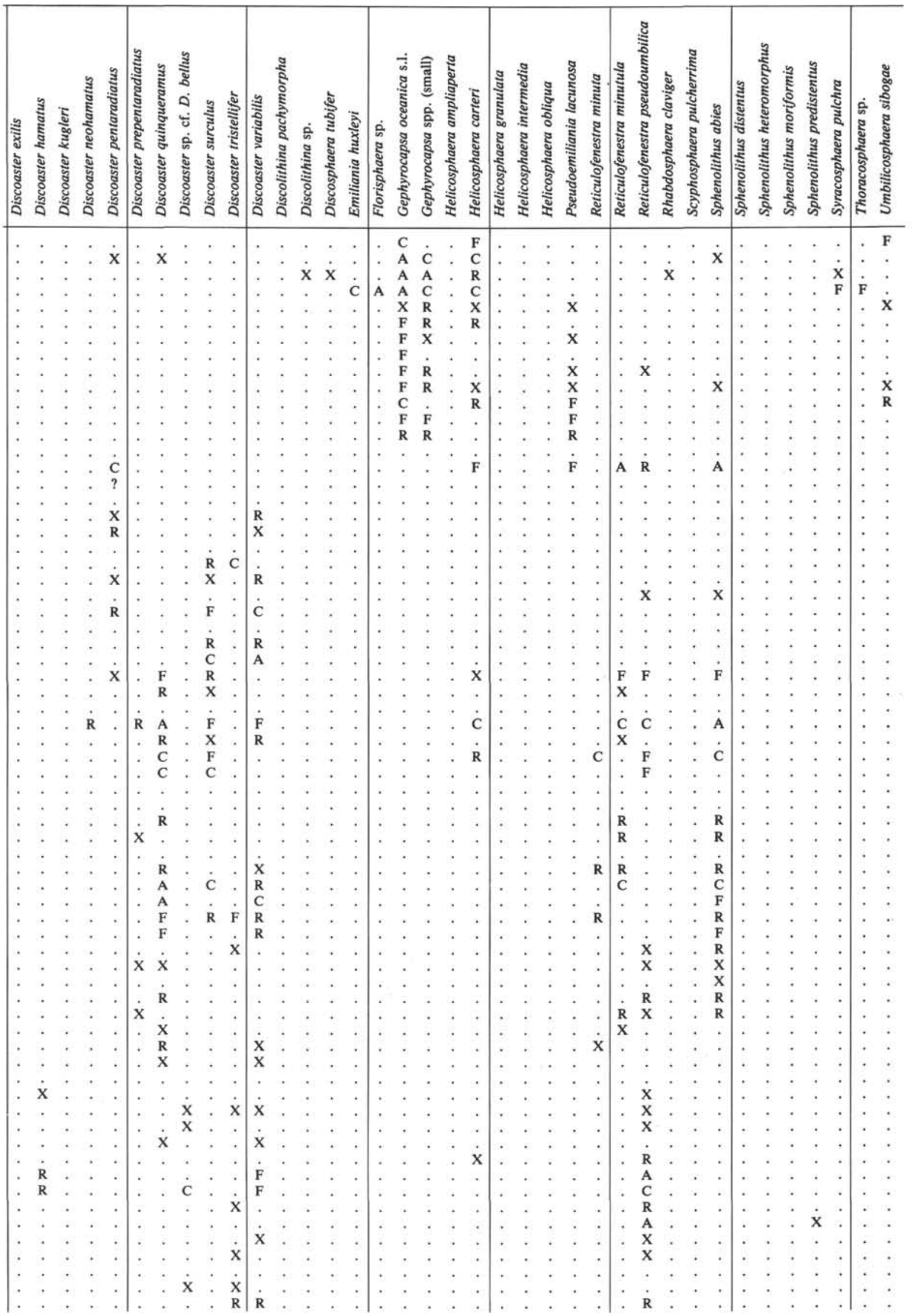

Figure 7 (continued). 


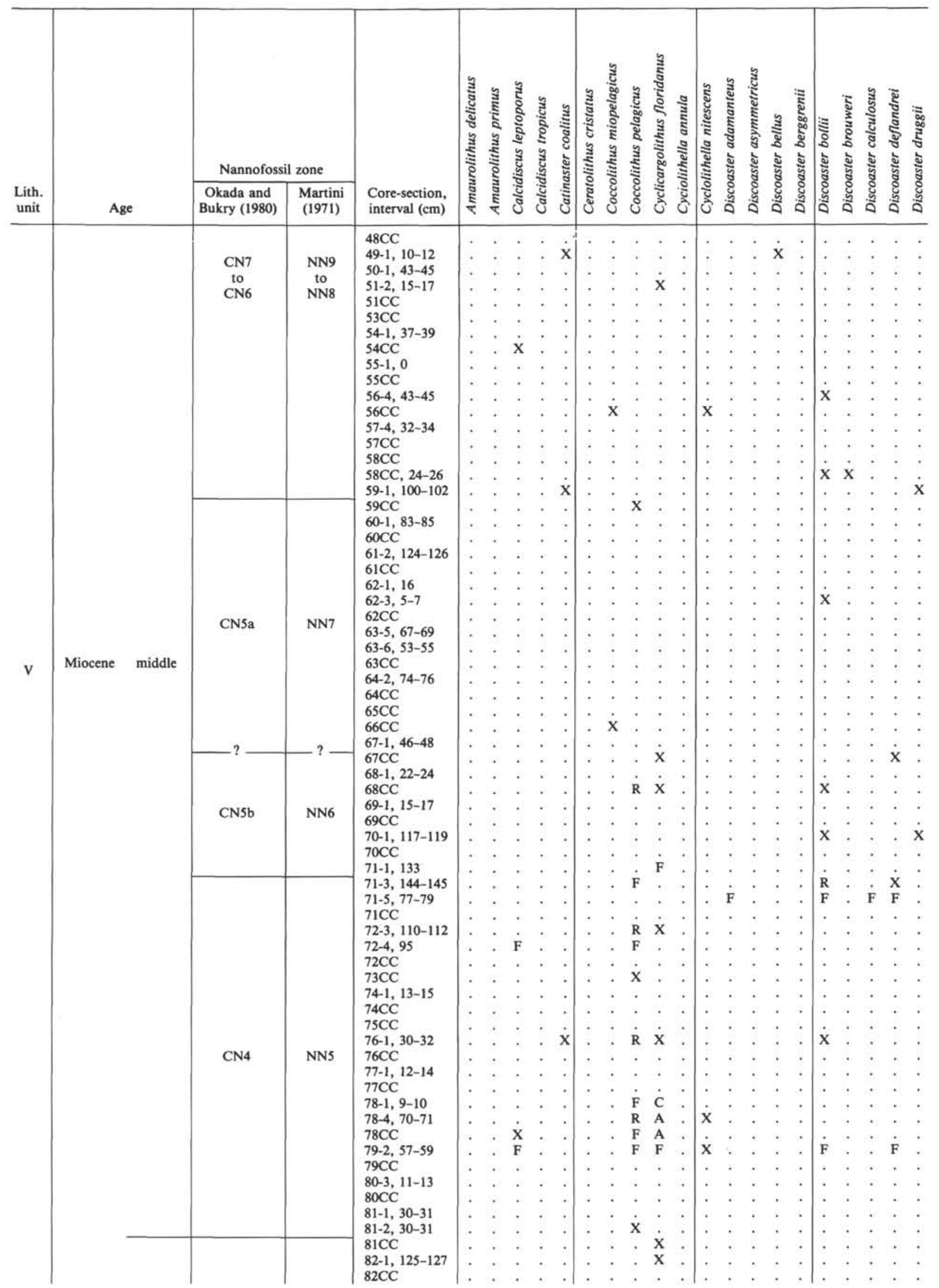

Figure 7 (continued). 
NEOGENE CALCAREOUS NANNOFOSSILS

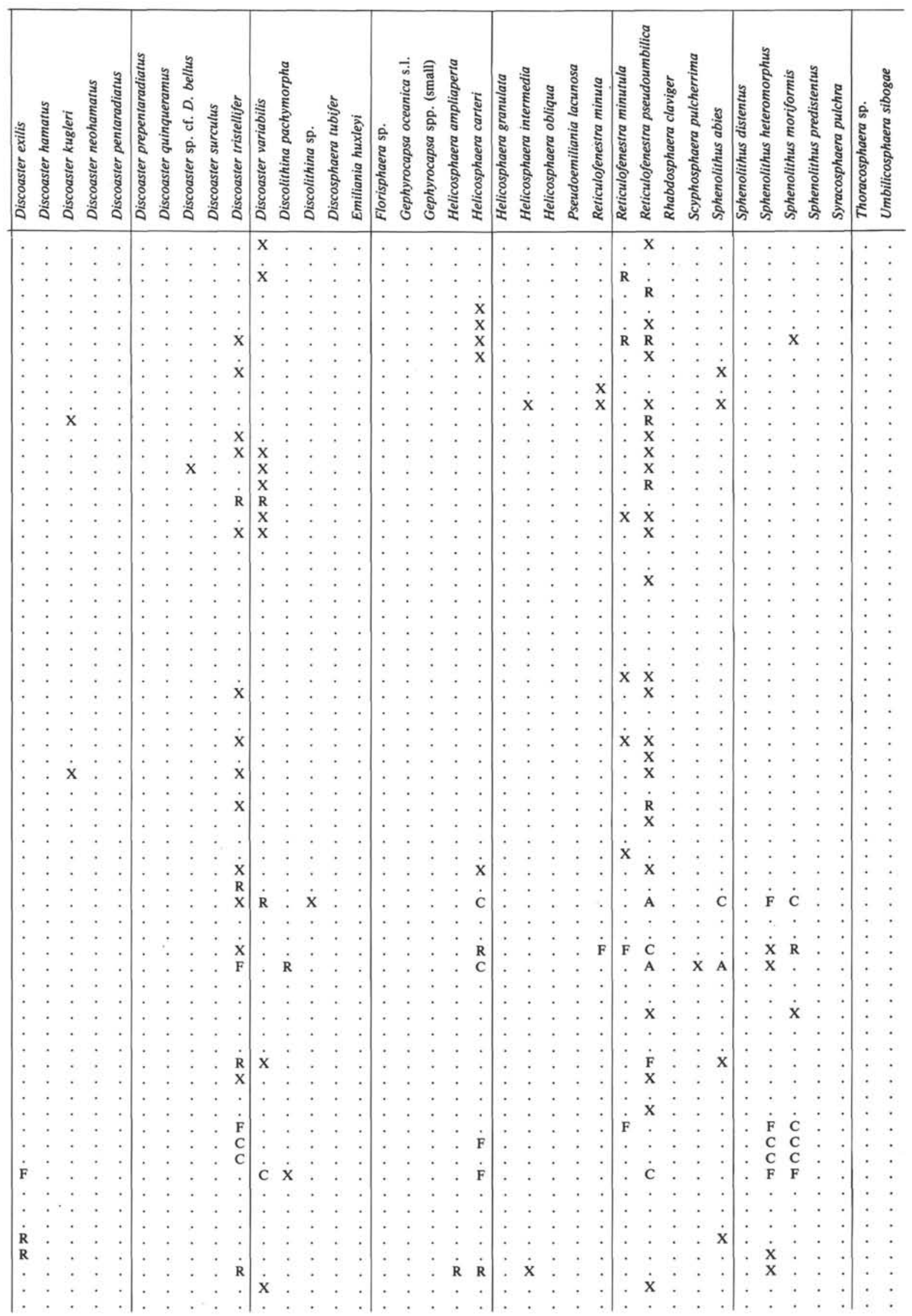

Figure 7 (continued). 


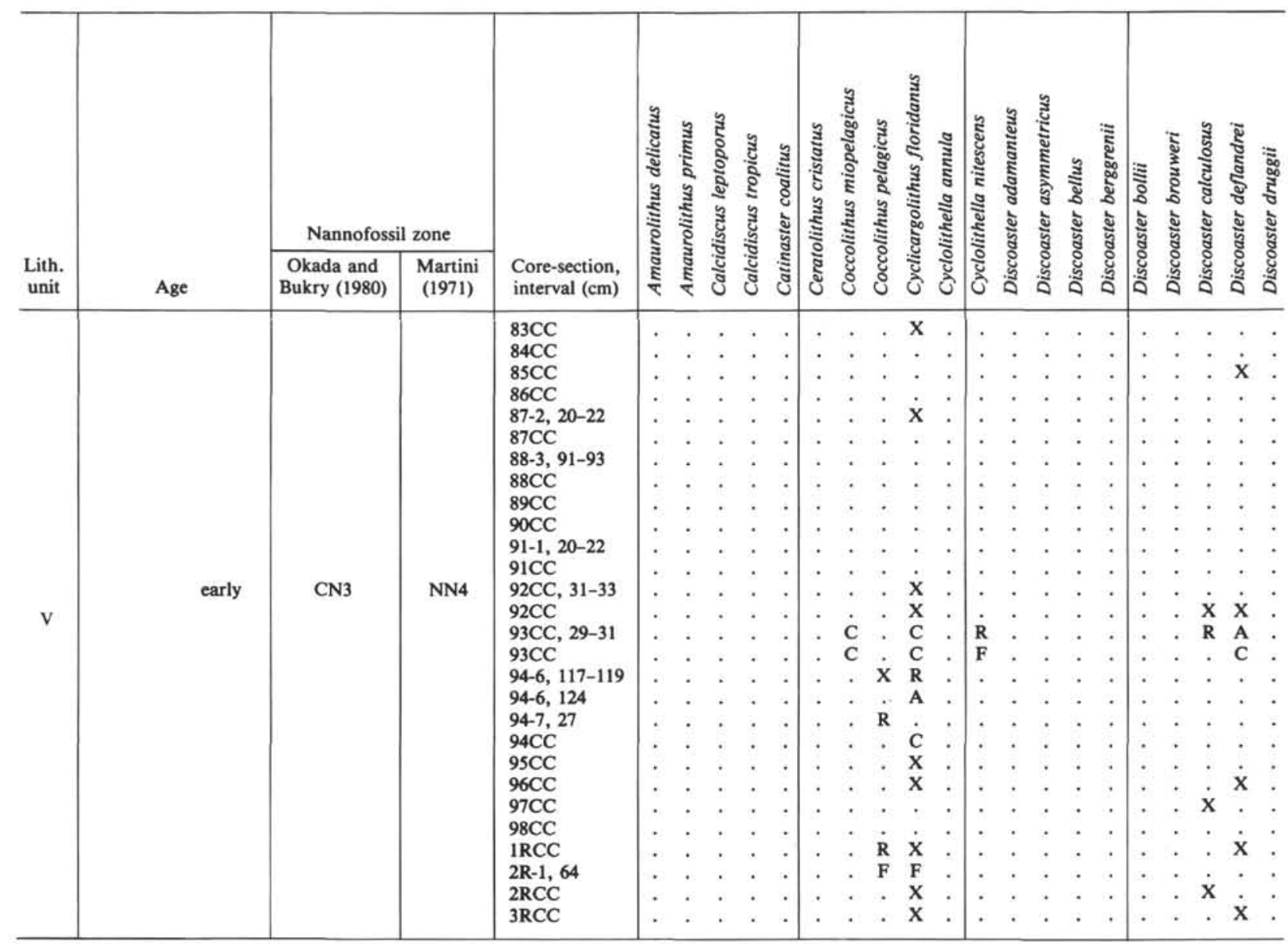

Key to symbols: $\mathrm{X}=$ very rare; $\mathrm{R}=$ rare; $\mathrm{F}=$ few $\mathrm{C}=$ common; $\mathrm{A}=$ abundant; $\mathrm{W}=$ very abundant; $?=$ questionably present; . = not present.

Figure 7 (continued).

also an isolated occurrence because the next four coring attempts yielded no sediment recovery, and the next downhole occurrence of Pseudoemiliania lacunosa is recorded in Sample 116-718C9X, CC (94.8 mbsf). A more precise determination of this datum cannot be made.

Next below this level is the lowest occurrence of Gephyrocapsa oceanica s.l. in Sample 116-718C-11X, CC (113.80 mbsf), which constrains the upper limit of the age of this level. From this datum downward to the highest occurrence of Discoaster quinqueramus in Sample 116-718C-16X-5, $148 \mathrm{~cm}$ (159.28 mbsf), sparse recovery and redeposition allow only a general Pliocene age assignment. If the assemblage from Sample 116-718C-13X-2, $126 \mathrm{~cm}(126.06 \mathrm{mbsf})$, is assumed to be in place and does indeed mark the highest occurrences of Sphenolithus abies and Reticulofenestra pseudoumbilica, then the entire late Pliocene and part of the early Pleistocene sequences are missing or represented by barren sediments. Alternatively, if the nannofossils found in Sample $116-718 \mathrm{C}-13 \mathrm{X}-2,126 \mathrm{~cm}$ (126.06 mbsf), are considered redeposited and the Sphenolithus abies and Reticulofenestra pseudoumbilica highest occurrences are taken at Sample 116-718C$15 \mathrm{X}-1,44-46 \mathrm{~cm}$ (142.75 mbsf), then the succession of highest occurrences of Discoaster surculus, Discoaster pentaradiatus, and Discoaster brouweri follows more nearly the reference succession, although that pattern is incompatible with the lowest occurrence of Pseudoemiliania lacunosa in Sample 116-718C$13 \mathrm{X}-2,126 \mathrm{~cm}$ (126.06 mbsf). The most reasonable interpretation seems to be that Sample 116-718C-13X-2, $126 \mathrm{~cm}$ (126.06 mbsf), does represent the lowest occurrence of Pseudoemiliania lacunosa and that the interval including the lowermost Pleistocene to mid-Pliocene sequences is greatly attenuated, riddled with hiatuses, or obscured by redeposition. Further support for this interpretation comes from the common occurrence of the early Pliocene Discoaster tristellifer in Sample 116-718C-14X-5, $140-142 \mathrm{~cm}$ (140.21 mbsf), but for which a magnetostratigraphic correlation has not been established. Beyond that, the biostratigraphy (and chronostratigraphy) of the Pliocene and earliest Pleistocene at Site 718 is unreadable.

The highest occurrence of Discoaster quinqueramus in Sample $116-718 \mathrm{C}-16 \mathrm{X}-5,148 \mathrm{~cm}(159.28 \mathrm{mbsf})$, is a robust datum in that it marks the top of reasonably consistent presence of the species. The age assignment is strengthened by the occurrence of Amaurolithus primus in Samples 116-718C-17X-6, $20 \mathrm{~cm}$ (169.0 mbsf), and 116-718C-19X-3, $33 \mathrm{~cm}$ (186.63 mbsf), and by the highest occurrence of Discoaster berggrenii in Sample 116-718C-17X-6, $20 \mathrm{~cm}$ (169.0 mbsf). From approximately this level the quality of biostratigraphy deteriorates again as the sediment becomes more silty and sandy. The Discoaster quinqueramus lowest occurrence is uncertain because specimens become progressively rare, and poor preservation makes differentiation from the antecedent species, Discoaster bellus, nearly impossible. The datum is placed in Sample 116-718C-35X, CC (341.8 mbsf), the lowest unequivocal occurrence of Discoaster quinqueramus.

The highest occurrence of Catinaster coalitus in Sample 116$718 \mathrm{C}-41 \mathrm{X}-2,64 \mathrm{~cm}$ (391.44 mbsf), is the next lower dependable datum. This datum is strengthened by the occurrence of Disco- 


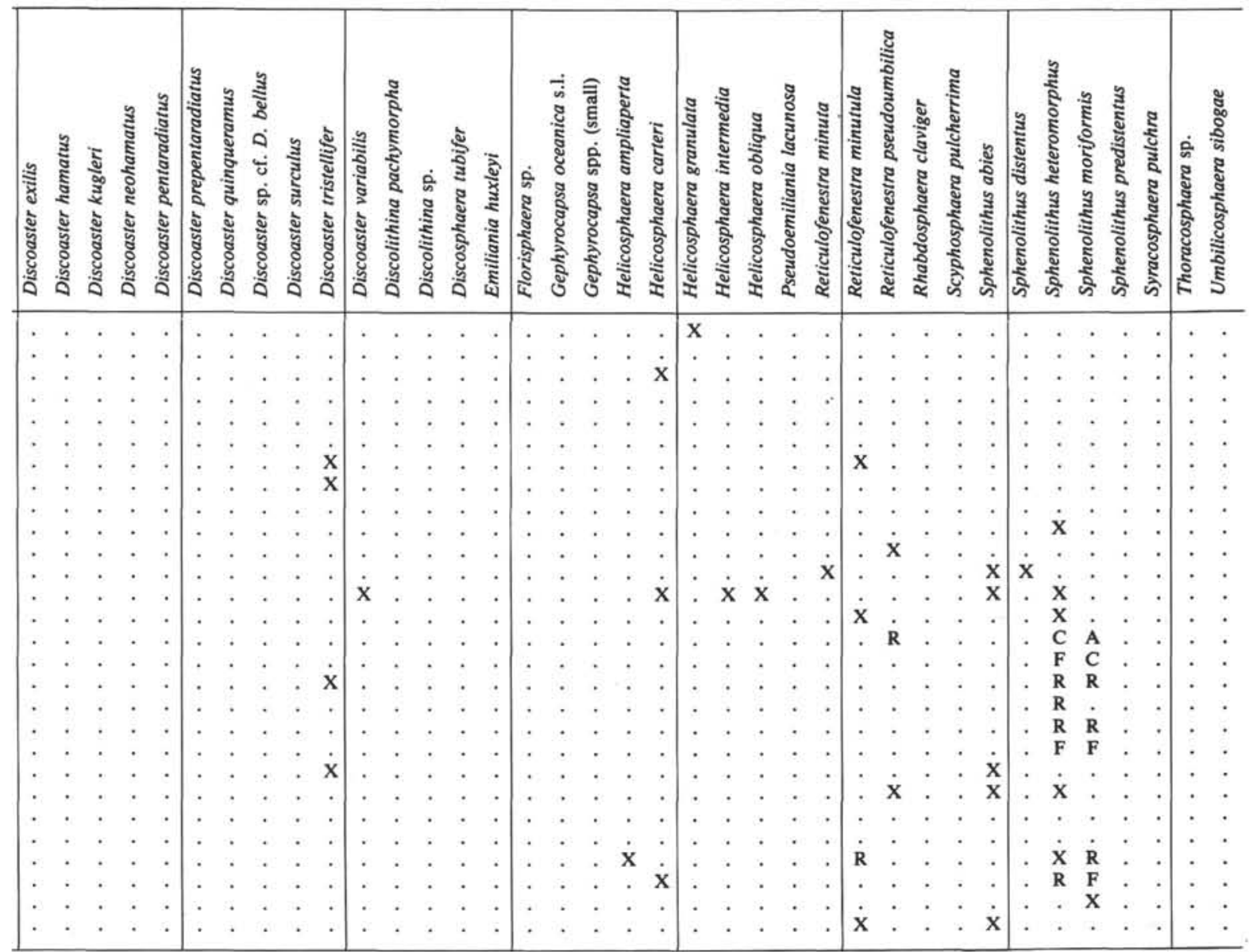

Figure 7 (continued).

aster hamatus at this level, although the latter species also has a single, very rare occurrence higher in the section in Sample 116718C-37X, CC (360.80 mbsf). The lowest occurrence of Catinaster coalitus in Sample 116-718C-59X-1, 100-102 cm (561.31 mbsf), also is an isolated, very rare occurrence; however, this datum is considered usable.

The next lower datum that is identified is the highest occurrence of Cyclicargolithus floridanus in Sample 116-718C-67X, CC (645.8 mbsf). This species is commonly redeposited, and the datum is identified in this section partly on its more or less consistent occurrence below this level, and partly on its inferred position relative to the next lower biohorizon, the highest occurrence of Sphenolithus heteromorphus in Sample 116-718C-71X-3, 143$145 \mathrm{~cm}$ (678.74 mbsf). The latter species is distinctive and can be considered a highly reliable marker in this hole.

The only remaining datum at this site is the highest occurrence of Helicosphaera ampliaperta in Sample 116-718C-81X, CC (778.80 mbsf). This same species was recorded from Sample 116-718E-1R, CC (942.60 mbsf); however, this lower occurrence probably does not represent the lower limit of the marker species as the next lower marker, the highest occurrence of Sphenolithus belemnos (not penetrated), is well above the lowest occurrence of Helicosphaera ampliaperta.

The nannofossil biostratigraphy seems consistently less readable at Site 718 than at the nearby Site 717 , which is difficult to explain. One possibility is that enhanced fluid circulation in the sediments at Site 718 (Cochran, Stowe, et al., 1989) has caused further destruction of calcareous nannofossils beyond that experienced at Site 717 .

\section{Site 719}

Site 719 is located between Sites 717 and 718 , on the same fault block as Site 717 , in an area where post deformation sediment thickness is greater than at Site 718 but less than at Site 717 (Fig. 2). The single hole drilled at Site 719 recovered sediment extending from the late Pleistocene-Holocene at the top into the late Miocene. The oldest nannofossil biomarker is the isolated occurrence of Amaurolithus amplificus in Sample 116$719-43 \mathrm{X}-1,16 \mathrm{~cm}$ (393.86 mbsf), and the bottom of the core is interpreted to be older than the lowest occurrence of this species, but probably younger than the lowest occurrence of Discoaster quinqueramus. Following is an analysis, interpretation, and justification of the biostratigraphy of this site. The checklist for this site is given in Figure 8.

Emiliania huxleyi is present in Sample 116-719-1X-1, $71 \mathrm{~cm}$ ( $0.71 \mathrm{mbsf}$ ) but disappears in an unfossiliferous interval immediately below the sediment surface. The next lower datum, the highest occurrence of Pseudoemiliania lacunosa, is in Sample 116-719-4X, CC (32.7 mbsf), and the marker species occurs with reasonable consistency from this level downward.

As at the previous two sites the early Pleistocene and latest Pliocene are greatly reduced in thickness, partly missing, riddled with redeposited older marker species, and plagued by poor recovery. This entire interval is, therefore, difficult to interpret, and the interpretation is subjective. Sample 116-719-17X-4, $40 \mathrm{~cm}$ ( $151.60 \mathrm{mbsf})$, is assigned to the mid-Pleistocene interval of dominance of small Gephyrocapsa, and a short distance below this, in Sample 116-719-17X-6, 42-43 cm (154.62 m), is the low- 


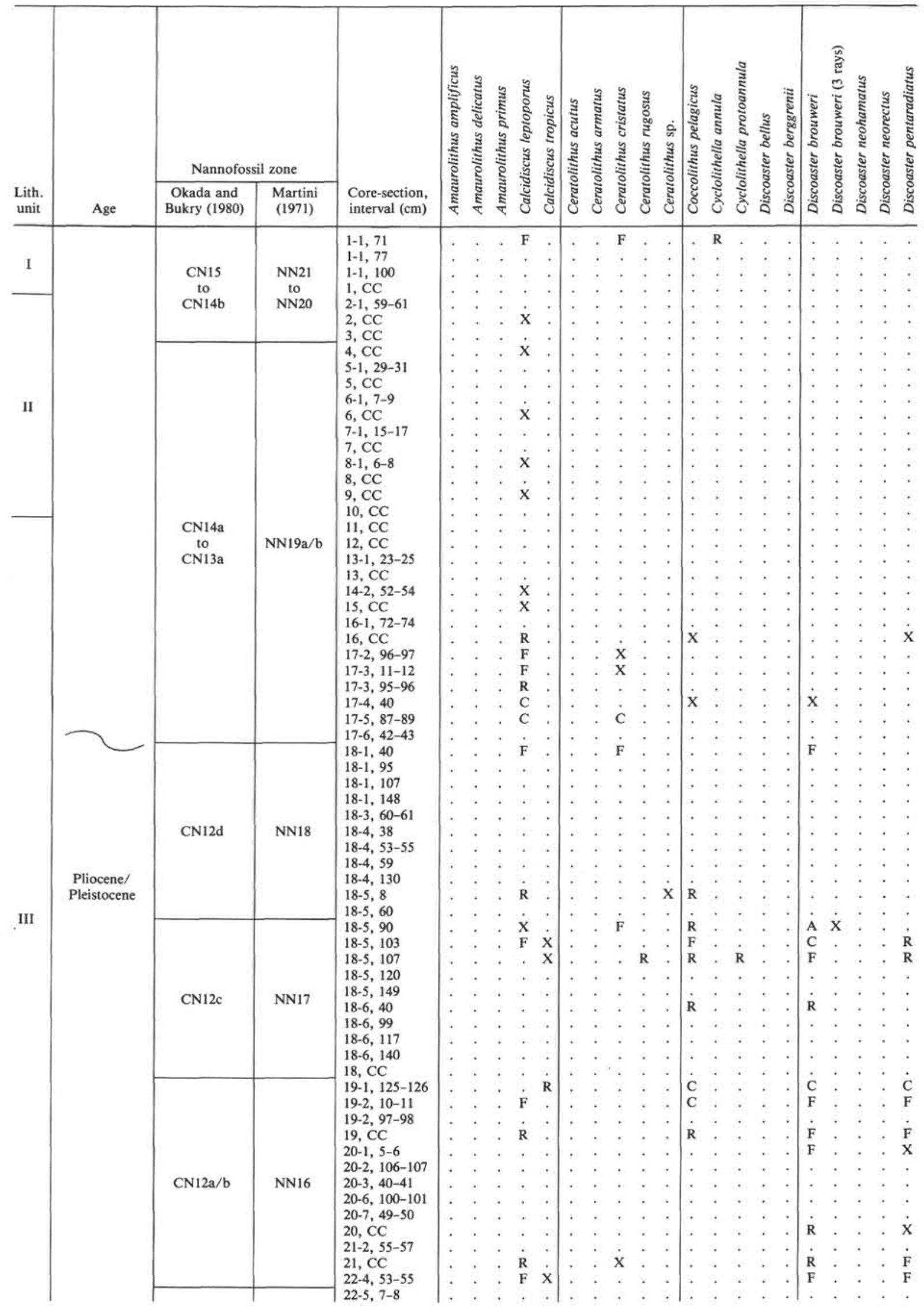

Figure 8. Checklist of calcareous nannofossils, Hole 719. 


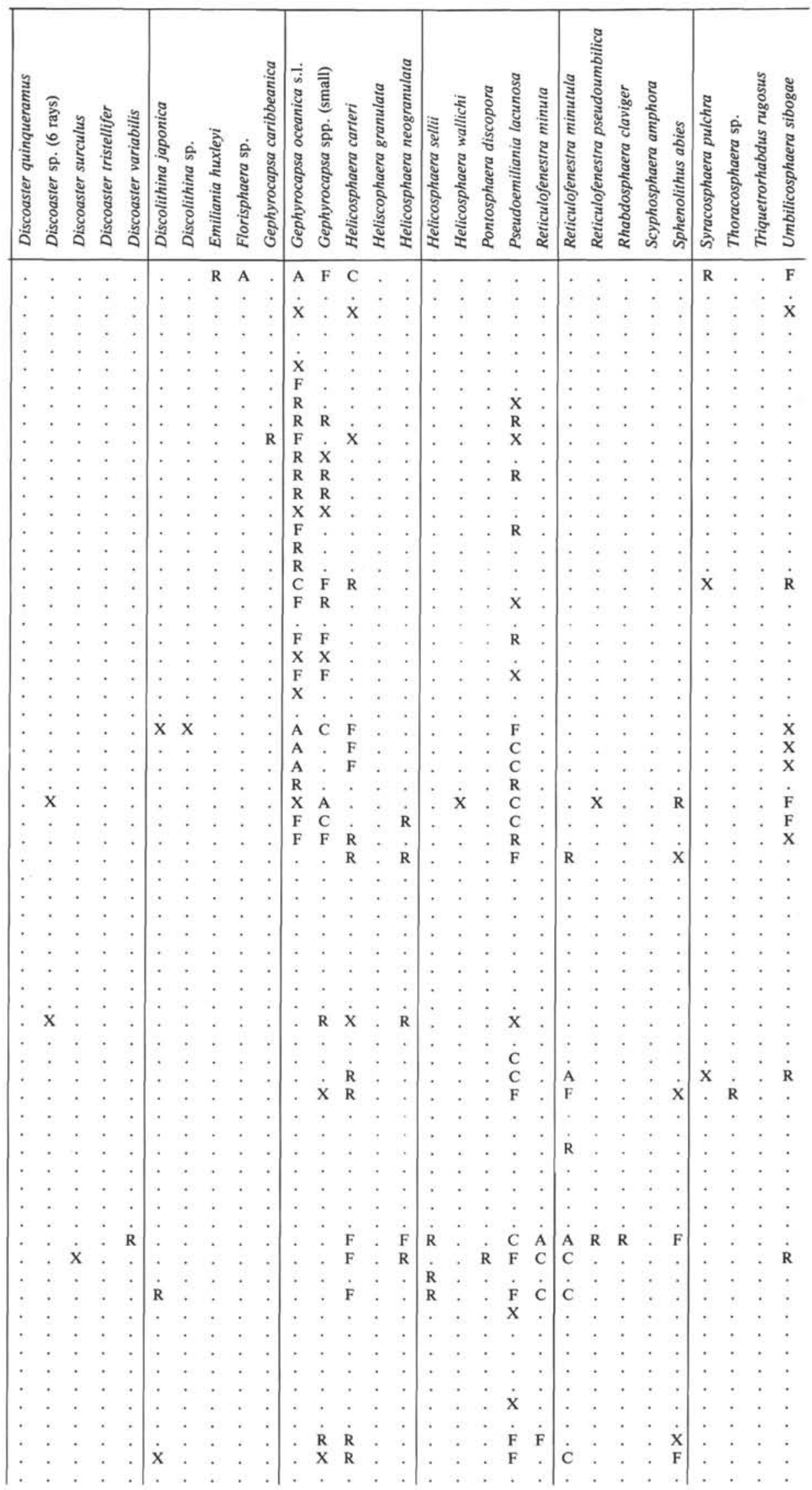

Figure 8 (continued). 


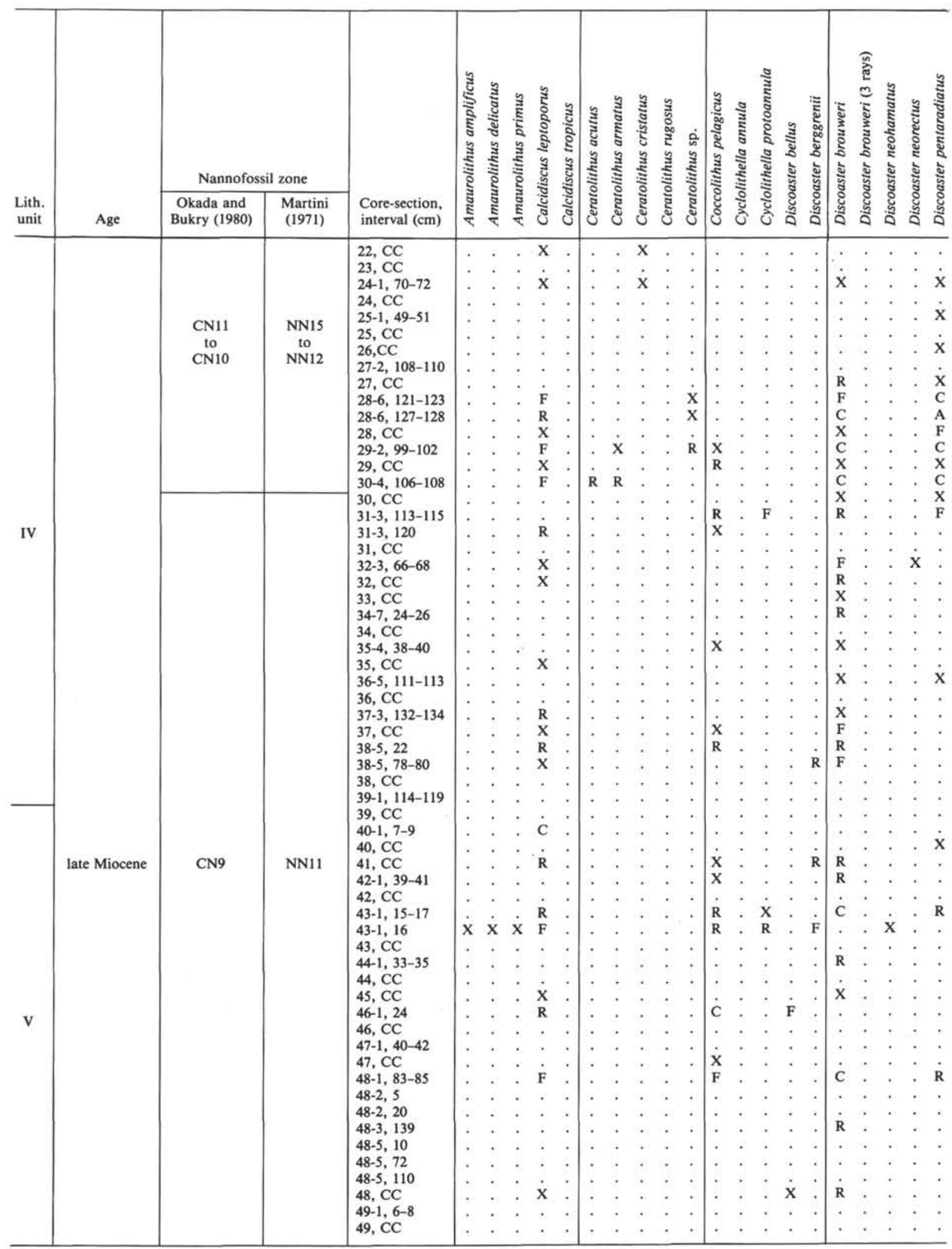

Key to symbols: $\mathrm{X}=$ very rare; $\mathrm{R}=$ rare; $\mathrm{F}=$ few; $\mathrm{C}=$ common; $\mathrm{A}=$ abundant; $\mathrm{W}=$ very abundant; ? $=$ questionably present; . = not present.

Figure 8 (continued). 


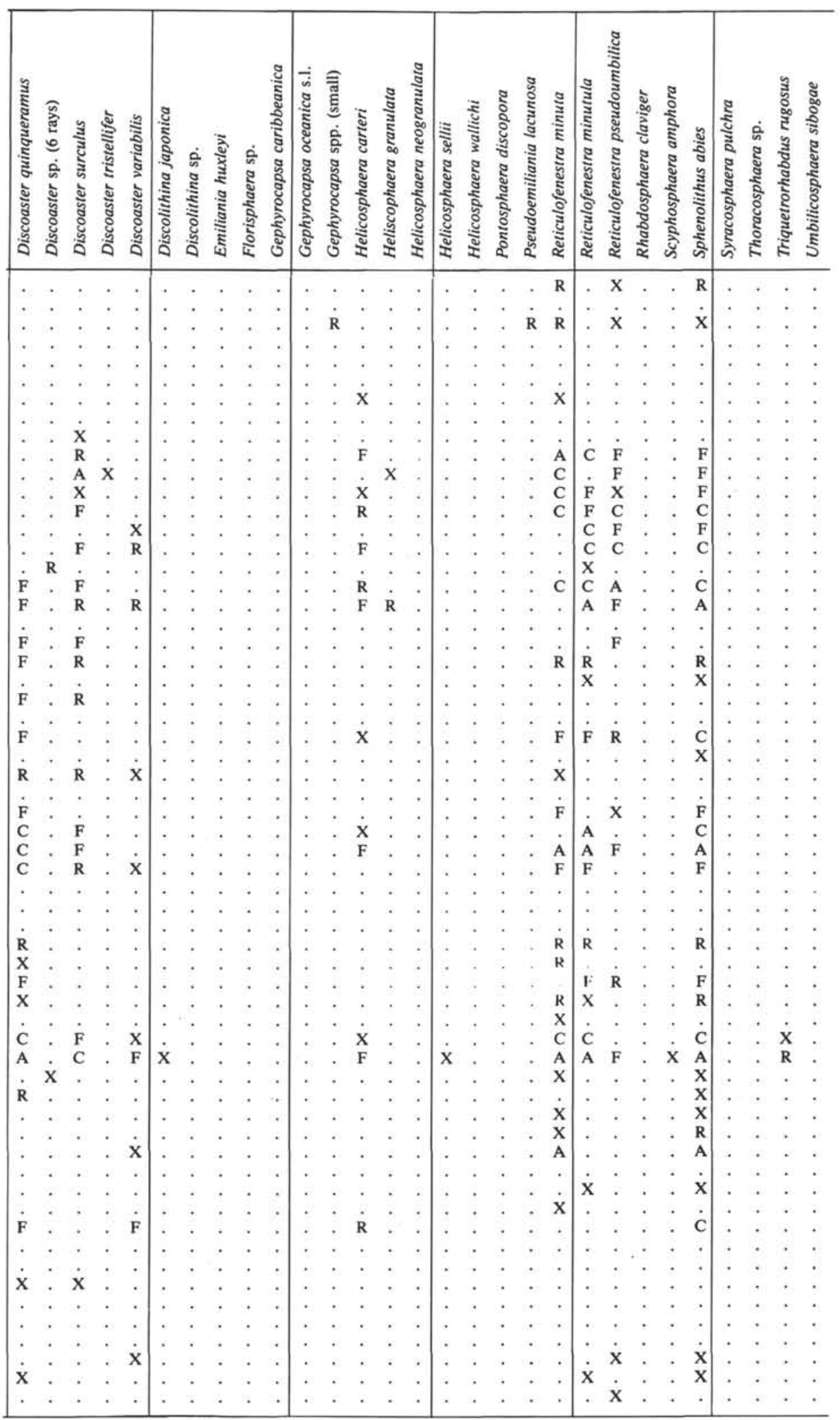

Figure 8 (continued). 
est occurrence of Gephyrocapsa oceanica s.1., which is here considered a more reliable marker than the small Gephyrocapsa datum.

The highest occurrence of Discoaster brouweri can be placed with equal justification in Sample 116-719-18X-1, $40 \mathrm{~cm}$ (156.60 mbsf), or Sample 116-719-18X-5, $90 \mathrm{~cm}$ (163.10 mbsf). Although the latter might be preferred because that level contains no obviously redeposited species, the next lower datum, the highest occurrence of Discoaster pentaradiatus, is in Sample 116-719-18X-5, $103(163.23 \mathrm{~m})$, just $13 \mathrm{~cm}$ farther down, which suggests that the Discoaster brouweri highest occurrence may actually be higher, i.e., in Sample 116-719-18X-1, $40 \mathrm{~cm}$.

The next lower datum, the highest occurrence of Discoaster surculus in Sample 16-719-19X-2, 10-11 cm (166.39 mbsf), is based on a single, isolated occurrence of that species and, thus, is not a very reliable marker. Next below, however, are three consecutive datums which, in combination, can be considered reliable markers. The highest occurrence of Sphenolithus abies is placed at Sample 116-719-21X, CC (194.20 mbsf); the highest occurrence of Reticulofenestra pseudoumbilica at Sample 116719-22X, CC (203.70 mbsf) and the lowest occurrence of Pseudoemiliania lacunosa is at Sample 116-719-24X-1, 70-72 cm (213.91 mbsf). The last of the three is the most reliable marker, whereas the first two could be considerably higher, as high as Sample 116-719-18X-5, $107 \mathrm{~cm}$ (163.27 mbsf), for Sphenolithus abies, and Sample 116-719-19X-1, 125-126 cm (176.45 mbsf), for Reticulofenestra pseudoumbilica.

Below the lowest occurrence of Pseudoemiliania lacunosa there follows first an interval of very poor recovery, then an interval of moderately good recovery. The latter extends from the early Pliocene into the late Miocene. The pertinent biohorizons are the lowest occurrence of Ceratolithus acutus and Ceratolithus armatus in Sample 116-719-30X-4, 106-108 cm (275.77 mbsf), followed a short distance below by the highest occurrence of Discoaster quinqueramus in Sample 116-719-31X-3, 113-115 $\mathrm{cm}$ ( $283.84 \mathrm{mbsf})$. The Miocene/Pliocene boundary is between the two biohorizons above in a very sparsely fossiliferous-tobarren turbidite sequence. The above combination of biohorizons is considered highly reliable, not subject to significant distortion or displacement.

Two additional markers were encountered below the Discoaster quinqueramus highest occurrence. These are the highest occurrences of Discoater berggrenii in Sample 116-719-38X-5, 78$80 \mathrm{~cm}$ (352.99 mbsf) and a single occurrence of Amaurolithus amplificus in Sample 116-719-43X-1, $16 \mathrm{~cm}$ (393.86 mbsf). Comparing the order of these last two biohorizons with the reference succession of biohorizons indicates that the Amaurolithus amplificus occurrence at this site probably approaches most nearly the lowest occurrence of that species. Below this level no further markers were recovered from the sparse, residual assemblages.

\section{DISCUSSION}

A detailed analysis of the calcareous nannofossils from the three sites of Leg 116 yielded some additional biostratigraphic control and, for the most part, confirms earlier observations. Age vs. depth (sediment accumulation rates) are replotted with the revised data in Figure 9 and, while the shapes of the sediment accumulation rate curves differ somewhat in detail, the overall picture remains the same. The multiple kinks in the sediment accumulation rate curve for Site 718 may be real or they may reflect mostly the poor quality of biostratigraphic control. Nevertheless, the highest sediment accumulation rate is evident from about 11 m.y. BP to about 7 m.y. BP at this site. Prior to 11 m.y., ago sediment accumulated somewhat more slowly. Between about 6 and 7 m.y. BP sediment accumulation decreased sharply and remained low to about 0.7 to $1 \mathrm{~m}$.y. BP, when it again increased sharply. At Site 717 sediment accumulation de-
Age (m.y.)

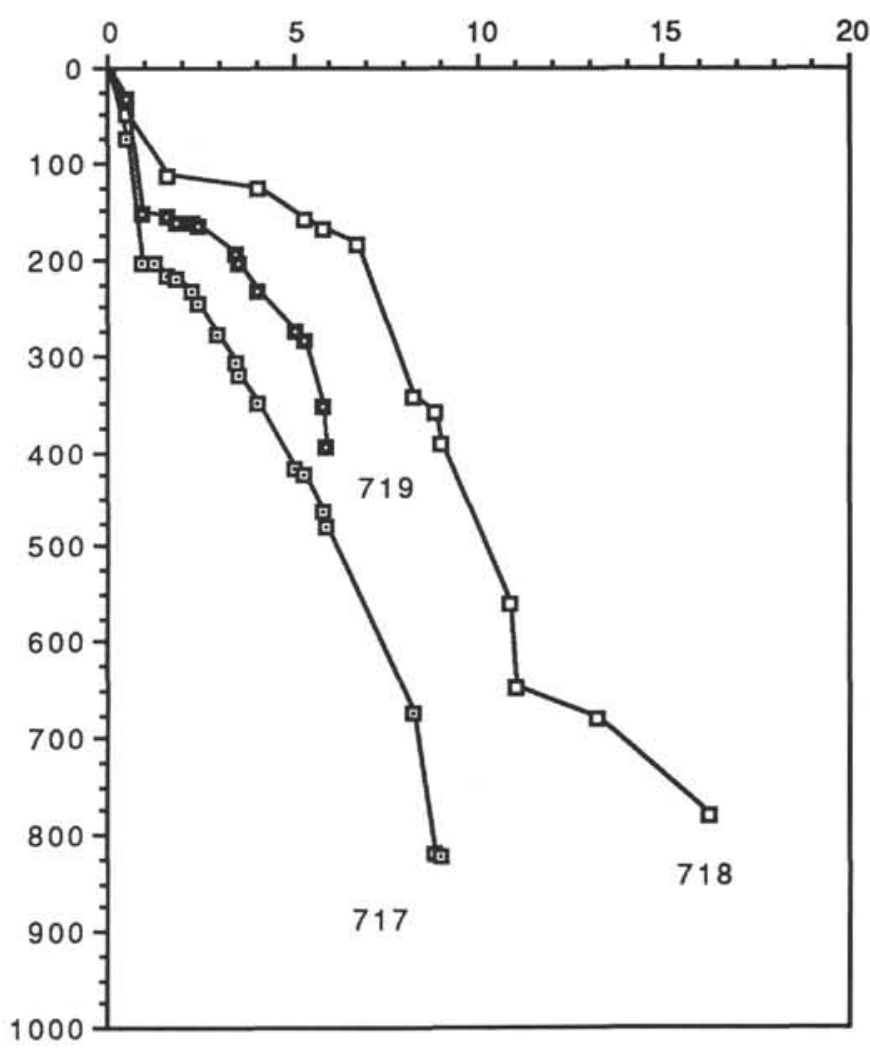

\section{Depth (m)}

Figure 9. Sediment accumulation rates (revised) from the distal Bengal Fan, Sites 717, 718, and 719 (data from Table 2).

creased much more gradually, starting at 6 to 7 m.y. BP, but a sharp reduction did not occur until about 2.5 m.y. BP. At Site 719 a more gradual decline in sediment accumulation commenced at about 5 m.y. BP and a sharp decline occurred at just over 2 m.y. BP. At all three sites high sediment accumulation resumed at about 1 m.y. BP or shortly thereafter, although at Site 718 core loss precludes precise biostratigraphic determination of critical biohorizons for this interval.

Owing to the sporadic recovery and poor preservation of fossil material, it is not possible to identify hiatuses clearly, although the episodic nature of deposition from turbidity currents probably ensures that only a fraction of the geological time spanned by these sediments is actually represented. It is virtually certain that there is a major hiatus in the early Pleistocene and late Pliocene at Site 718, and there are probably multiple lesser hiatuses over this same interval at Sites 717 and 718 . Thus, it is perhaps expecting too much to extract better resolution from these sections than has been obtained. On reflection it is surprising that any biostratigraphy at all could be extracted from the sediments of the distal Bengal Fan. Preservation of direct pelagic influx of calcareous (and silicious) biogenic sediment cannot be confirmed (except for the surface veneer), which suggests that deposition has occurred at or below the regional CCD. The surface veneer of pelagic carbonate probably will not survive burial into the fan. The calcareous fossils that have been preserved probably owe their survival to rapid burial in and by 
turbidites. The thin white laminae of biogenic carbonate, some of which clearly show graded bedding and almost certainly are of turbidite origin, probably survived dissolution because they were quickly buried by subsequent turbidity-flow deposits of fine-grained, impermeable, clayey sediments. It should be noted also that in a hostile (corrosive) environment it is generally the redeposited nannofossils that constitute the bulk of the residue after most indigenous species have been dissolved. It is not uncommon to recover well-preserved redeposited Cretaceous coccoliths from hemipelagic sediments in the Gulf of Mexico in which indigenous species are rare, severely corroded, often represented only by faint ghostlike shapes nearly devoid of calcium carbonate. Disquieting as it is, the conclusion that the entire biostratigraphy of the distal Bengal Fan is based on redeposited fossils seems inescapable. All interpretation must, therefore, allow for the possibility that any of the age assignments made from fossils might, in fact, be too old.

\section{SUMMARY AND CONCLUSIONS}

The three sites drilled on ODP Leg 116 recovered mostly, possibly only, turbidite sediments from the distal Bengal Fan. Calcareous nannofossil assemblages were recovered sporadically at each site; however, it is safest to assume that all fossil material has been redeposited by turbidity currents. In spite of pervasive redeposition it is possible to devise a sensible, though somewhat uneven and uncertain, biostratigraphy for these three sites. Lowest occurrence datums proved most dependable, among them the lowest occurrences of Gephyrocapsa oceanica s.l.; the lowest occurrence of Pseudoemiliania lacunosa; the lowest occurrence of Ceratolithus armatus; the lowest occurrence of Amaurolithus amplificus (in combination with the highest occurrence of Discoaster berggrenii); and the lowest occurrence of Discoaster quinqueramus.

The oldest sediments were recovered at Site 718 where the lowest datum penetrated is the highest occurrence of Helicosphaera ampliaperta (16.0 m.y.) well above the bottom of the hole. Site 717 penetrated the highest occurrence of Catinaster coalitus $(9.0$ m.y.), and Site 719 was cored to below the lowest occurrence of Amaurolithus amplificus.

Site 718 proved to be the most intractable biostratigraphically, and the exceptionally poor recovery of nannofossils may be related to the peculiar fluid circulation in the sediments recognized at this site.

A major hiatus is recognized at Site 718 , where much of the late Pliocene and early to mid-Pleistocene section may be missing. This hiatus probably resulted from local deformation. Sediment accumulation seems to have continued sporadically at Sites 717 and 719 . Multiple shorter hiatuses are probably present at these sites, but occur with a frequency too high to be resolved using the available biostratigraphy.

Finally, all interpretation of the distal Bengal Fan sites must allow for the possibility that every age assignment made on highest occurrences may be too old. Age assignments based on lowest occurrences may be too old also because sparse and sporadic occurrences of marker species in the generally unfavorable lithology may prevent recognition of true lowest occurrences.

\section{ACKNOWLEDGMENTS}

This study was supported by the National Science Foundation, U.S. Science Program. The manuscript has benefitted from reviews by Joanne Sblendorio-Levy and Wu-Cheng Wei.

\section{REFERENCES}

Baldauf, J. G., Thomas, E., Clement, B., Takayama, T., Weaver, P.P.E., Backman, J., Jenkins, G., Mudie, P. J., and Westberg-Smith, M. J., 1987. Magnetostratigraphic and biostratigraphic synthesis, Deep Sea Drilling Project Leg 94. In Ruddiman, W. F., Kidd, R. B., et al., Init. Repts. DSDP, 94 (Pt. 2): Washington (U.S. Govt. Printing Office), 1159-1205.

Berggren, W. A., Kent, D. V., Flynn, J. J., and van Couvering, J. A., 1985a. Cenozoic geochronology. Geol Soc. Am. Bull., 96:1407-1418.

Berggren, W. A., Kent, D. V., and Van Couvering, J. A., 1985b. The Neogene: Part 2. Neogene geochronology and chronostratigraphy. In Snelling, N. J. (Ed.), The Chronology of the Geological Record: Geol. Soc. London Mem., 10:211-260.

Bukry, D., 1971. Cenozoic calcareous nannofossils from the Pacific Ocean. Trans. San Diego Soc. Nat. Hist., 6:303-327.

Clement, B. M., and Robinson, F., 1987. The magnetostratigraphy of Leg 94 sediments. In Ruddiman, W. F., Kidd, R. B., et al., Init. Repts. DSDP, 94 (Pt. 2): Washington (U.S. Govt. Printing Office), 635-650.

Cochran, J. R., Stow, D.A.V., et al., 1989. Proc. ODP, Init. Repts., 116: College Station, TX (Ocean Drilling Program).

Gartner, S., Chen, M. P., and Stanton, R. J., 1983. Late Neogene nannofossil biostratigraphy and paleoceanography of the northeastern Gulf of Mexico and adjacent areas. Mar. Micropaleontol., 8:7-50.

Martini, E., 1971. Standard Tertiary and Quaternary calcareous nannoplankton zonation. In Farinacci, A. (Ed.), Proc. Second Planktonic Conf. Roma, 1971: Rome (Ed. Tecnoscienza), 739-785.

Mazzei, R., Raffi, I., Rio, D., Hamilton, N., and Cita, M. B., 1979. Calibration of late Neogene calcareous plankton datum planes with the paleomagnetic record of Site 397 and correlation with Moroccan and Mediterranean sections. In von Rad, U., Ryan, W.B.F., et al., Init. Repts. DSDP, 47 (Pt.1): Washington (U.S. Govt. Printing Office), 375-389.

Miller, K. G., Kahn, M. J., Aubry, M-P., Berggren, W. A., Kent, D. V., and Melillo, A., 1985. Oligocene-Miocene biostratigraphy, magnetostratigraphy, and isotopic stratigraphy of the Western North Atlantic. Geology, 13:257-261.

Okada, H. and Bukry, D., 1980. Supplementary modification and introduction of code numbers to the low latitude coccolith biostratigraphic zonation (Bukry, 1973; 1975). Mar. Micropaleontol., 5:321325.

Perch-Nielsen, K., 1985. Cenozoic calcareous nannofossils. In Bolli, H. M., Saunders, J. B. and Perch-Nielsen, K. (Eds.), Plankton Stratigraphy: Cambridge, U.K. (Cambridge Univ. Press), 427-554.

Poore, R. Z., Tauxe, L., Percival, S. F., LaBrecque, J. L., Wright, R., Petersen, N. P., Smith, C. C., Tucker, P., and Hsü, K. J., 1984. Late Cretaceous-Cenozoic magnetostratigraphic and biostratigraphic correlation for the South Atlantic Ocean, Deep Sea Drilling Project Leg 73. In Hsü, K. J., LaBrecque, J. L., et al., Init. Repts. DSDP, 73: Washington (U.S. Govt. Printing Office), 645-655.

Prell, W. L., Imbrie, J., Martinson, D. G., Morley, J. J., Pisias, N. G., Shackleton, N. J., and Streeter, H. F., 1986. Graphic correlation of oxygen isotope stratigraphy application to the late Ouaternary. Paleoceanography, 1:137-162.

Rio, D., Backman, J., and Raffi, I., 1988. Calcareous Nannofossil Biochronology and the Pliocene/Pleistocene Boundary. Universita Degli Studidi Parma (Preprint).

Takayama, T., and Sato, T., 1987. Coccolith biostratigraphy of the North Atlantic Ocean, Deep Sea Drilling Project Leg 94. In Ruddiman, W. F., Kidd, R. B., et al., Init. Repts. DSDP, 94 (Pt. 2): Washington (U.S. Govt. Printing Office), 651-702.

Date of initial receipt: 11 May 1989 Date of acceptance: 30 November 1989 Ms 116B-122 